\title{
More than just a beer-the potential applications of by-products from beer manufacturing in polymer technology
}

\author{
Aleksander Hejna ${ }^{1}[$
}

Received: 8 June 2021 / Accepted: 8 September 2021 / Published online: 24 September 2021

(c) The Author(s) 2021

\begin{abstract}
Beer is the most popular alcoholic beverage in the world, and its popularity is continuously growing. Currently, global beer production is estimated at around 2 billion hectoliters. Nevertheless, the increasing production capacity implicates the rising issue of generated by-products-brewers' spent grain, spent hops, spent yeast, and wastewater. They are generated in massive amounts, so having in mind the current pro-ecological trends, it is crucial to look for their utilization methods. Among the possibilities, particular attention should be drawn to polymer technology. This sector can efficiently use different lignocellulosic materials, which could be applied as fillers for polymer composites or sources of particular chemical compounds. Moreover, due to their chemical composition, brewing industry by-products may be used as functional fillers and additives. They could be introduced to enhance the materials' resistance to oxidation, microbes, or fungi. These issues should be considered especially important in the case of biodegradable polymers, whose popularity is growing over the last years. This paper summarizes the literature reports related to the composition and potential applications of the brewing industry by-products in polymer technology. Moreover, potential directions of research based on the possibilities offered by the brewing industry by-products are presented.
\end{abstract}

Keywords Brewing by-products $\cdot$ Beer $\cdot$ Brewers' spent grain $\cdot$ Spent hops $\cdot$ Spent yeast $\cdot$ Trub $\cdot$ Wood polymer composites $\cdot$ Polymer materials

\section{Introduction}

As a process aimed at beer production, brewing is known for thousands of years [1]. Depending on the times and mainly the development of humanity and science, the specifics of this process were changing [2]. Figure 1 presents the current general scheme of beer production. Generally, the brewing process consists of the following stages, starting from the malt: crushing of malt, mashing, lautering, filtration, boiling, and fermentation. At first, malt is crushed to break apart the kernel and facilitate the extraction of sugars during mashing [3].

Then, crushed malt is mixed with hot water in a mash tun creating the cereal mash. Naturally occurring enzymes present in the malt convert the starch extracted from the malt into simpler fermentable and non-fermentable sugars

Aleksander Hejna

aleksander.hejna@pg.gda.pl; ohejna12@gmail.com

1 Department of Polymer Technology, Gdańsk University of Technology, Narutowicza 11/1280-233, Gdańsk, Poland in the saccharification process [4]. To enhance the yield of mashing, in the end, the mas is often heated up to $76-78^{\circ} \mathrm{C}$, which is called mashout, and sprinkled with additional water during sparging [5]. Such processes are implemented to reduce mash viscosity, free up more starch, and extract additional sugars [6]. As a result, a sugar-rich liquid called wort is obtained after separation from the solid residue of mashing called the brewers' spent grain (BSG) [7].

The wort is moved to the kettle, where it is boiled with hops (and sometimes other ingredients). The boiling process aims to terminate the enzymatic processes, precipitate proteins, concentrate and sterilize the wort, as well as extract compounds from hops to beer and isomerize hop resins to add bitterness to beer [8]. Moreover, boiling may induce caramelization and Maillard reactions in wort [9]. In the end, the hopped wort is cooled down and separated from the trub, which includes the hop residues and colloidal proteins coagulated during boiling [10].

Cooled and hopped wort is transferred to the fermentation tanks and pitched with yeast, converting the fermentable sugars into alcohol and carbon dioxide. Moreover,

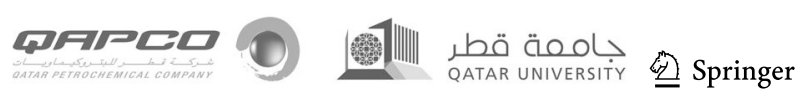


Fig. 1 The general scheme of beer production with an indication of generated by-products

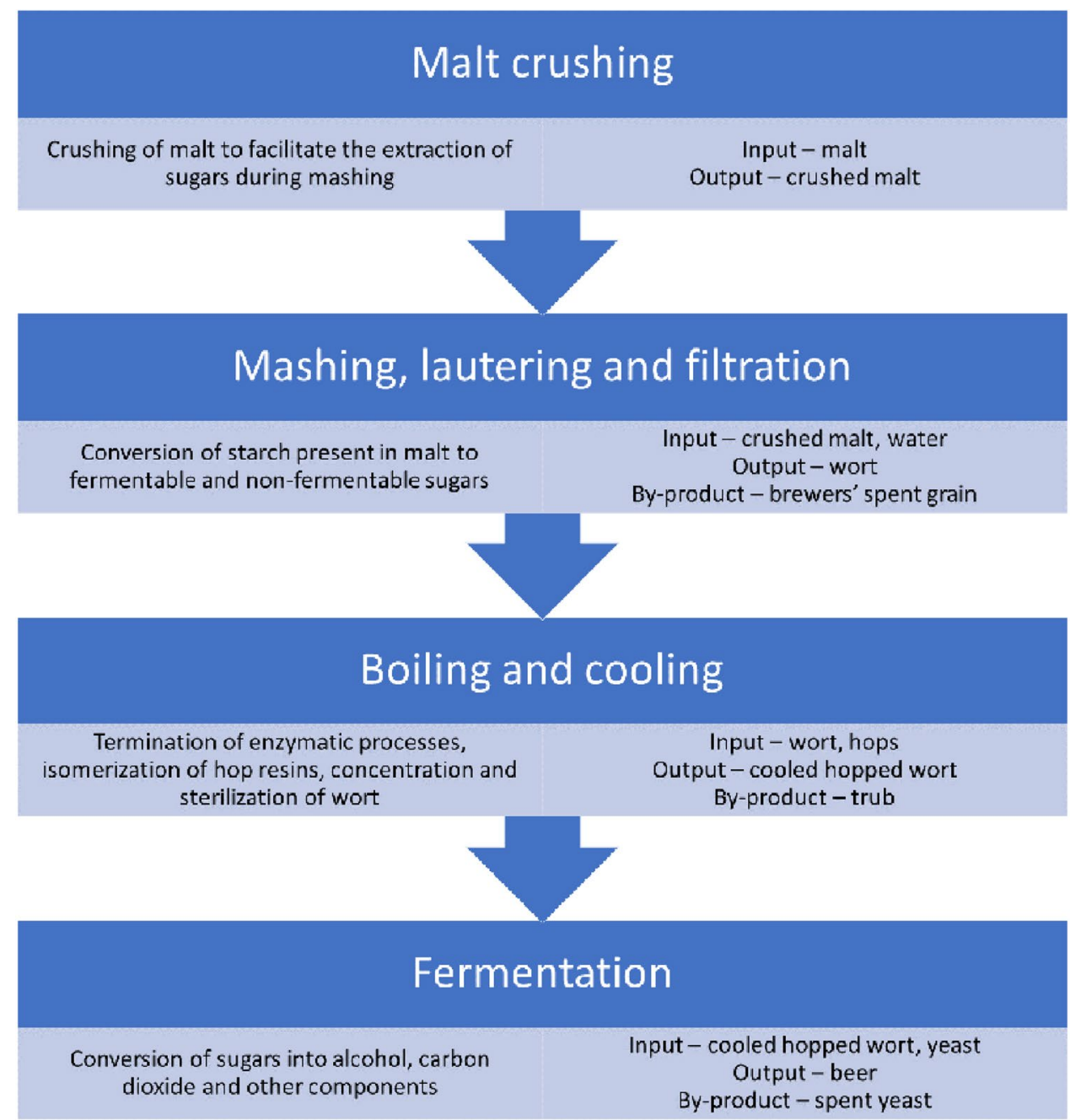

depending on the type of yeast, different reactions occur, which account for the beer's final taste and aroma profile [11]. After complete fermentation, the beer is separated from the surplus yeast, called spent yeast, conditioned in the additional tank, and packed into bottles, casks, or cans [12].

\section{Beer production statistics}

Beer is the most popular alcoholic beverage globally and the third most popular beverage after water and tea [13]. The global beer production size is relatively stable in the last decade and accounts for 1.91-1.97 billion hectoliters [13]. The leading producer is China, whose production in 2019 equaled 376.5 million hectoliters and accounted for $\sim 20 \%$ of global production [14]. The Americas occupy the following positions-the United States, Brazil, and Mexico with 210.3, 144.8, and 124.2 million hectoliters, respectively [15]. Considering Europe, the size of production exceeds 420 million hectoliters annually [16]. The share of particular continents in the global beer production is presented in Fig. 2. The biggest producer is Germany, the country with great brewing traditions. In 2019, Germans produced 91.6 million hectoliters of beer, mostly pilsener and wheat beer [17]. In Europe, Germany is followed by Poland and the UK, whose production is around 40 million hectoliters [18]. It is also essential to mention Russia as a critical producer with 77.4 million hectoliters produced in 2019 [19]. Russia is one of the few countries where beer is not the most popular alcoholic beverage, with a higher vodka share [20]. Presented data indicate that global beer production is distributed across all the regions of the world. Therefore, research activities related to the manufacturing, consumption, and health aspects and the utilization of by-products of beer production are essential because these aspects may affect an enormous number of people worldwide.

\section{Beer production by-products}

Conventionally, beer is produced from barley and, to a noticeably lesser extent, from wheat [21]. Such a production model is commonly applied in Europe. Moreover, in 
Fig. 2 The share of particular continents in the global beer production

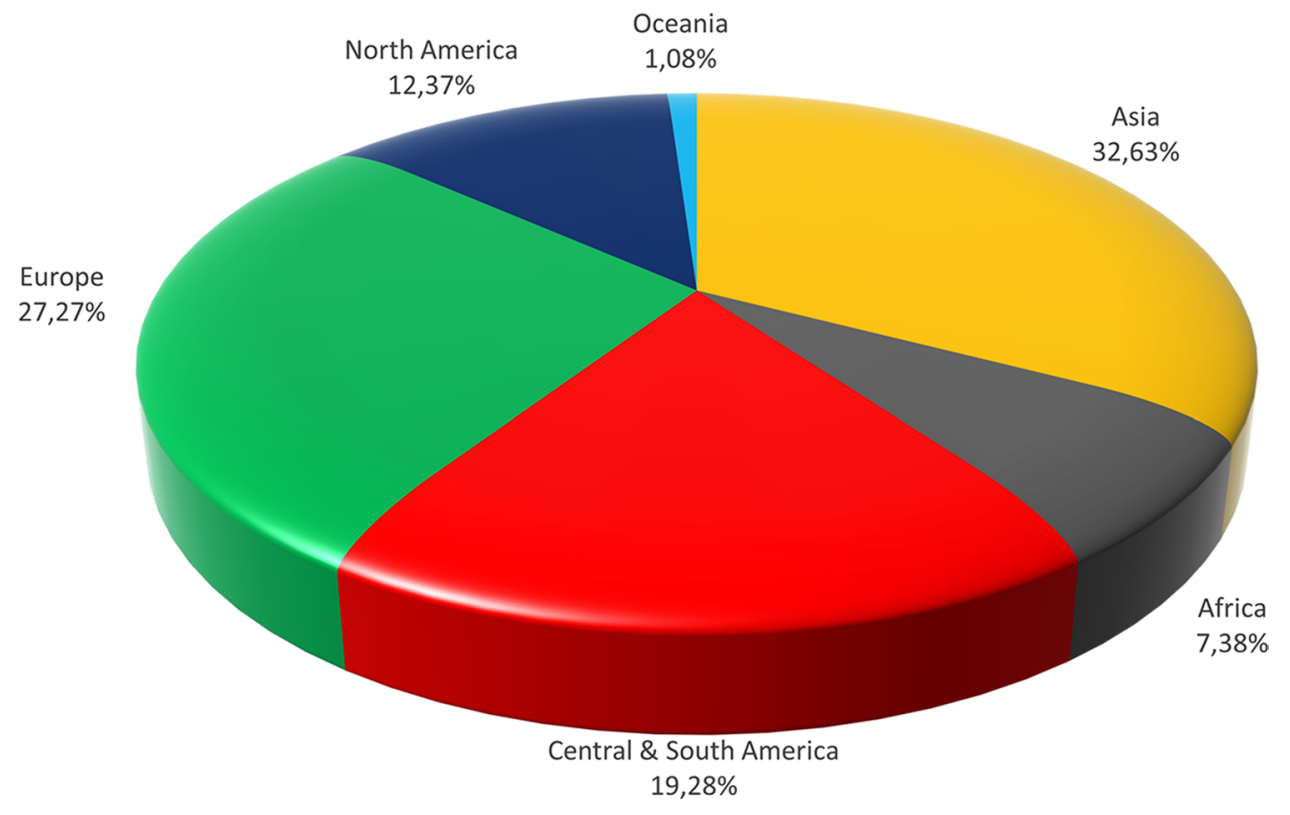

Germany, such issues are regulated by Germany's Beer Purity Law, originating from the medieval Bayreisches Reinheitsgebot [22]. Nevertheless, in different regions of the world, other starch sources are also applied, such as maize in America [23], rice in Asia [24], or sorghum in Africa [25]. Considering hops and yeast, their use is associated with the desired beer style. The market offers an enormous range of hops and yeast varieties [26, 27].

According to the brewing scheme presented in Fig. 1, the main by-products of beer manufacturing are the brewers' spent grain, trub removed after wort boiling, and spent yeast. The generation of brewing by-products is very similar globally, with possible differences in their composition, depending on the location. These materials are currently often unutilized and present hardly any market value. Generally, considering the current pro-environmental trends in scientific and industrial activities partially stimulated by the changing law regulations established worldwide, waste and by-products management are essential [28]. Except for the environmental motivations, the application of such materials in various production processes can generate added value for the resulting products (enhanced performance or new properties) or reduce their manufacturing costs [29].

One of the industry branches where by-products from beer manufacturing could be potentially applied in polymer technology. This sector of the industry is enormously dependent on petroleum price and availability [30]. It is commonly known that its resources are constantly shrinking, and it is essential to seek new raw materials, which could substitute petroleum, beneficially from renewable resources [31]. In the following sections, the literature reports on the applications of brewing by-products in polymer technology would be discussed.

\subsection{Brewers' spent grain}

\subsubsection{Overview}

The main and the most abundant by-product generated by the brewing industry is brewers' spent grain. It is generated in high amounts and accounts for over $85 \%$ of beer manufacturing by-products [32]. During the mashing process, around $69 \%$ of the initial malt mass is extracted and converted to sugars soluble in wort [33]. Considering that production of the one hectoliter of beer uses $20 \mathrm{~kg}$ of malt, around $6.2 \mathrm{~kg}$ of dry BSG is generated. Such values are typical for the most popular beer style worldwide_-light lager [34]. Other beer styles, especially those characterized by higher original gravity, require higher malt loadings, even up to $45 \mathrm{~kg}$ for strong stouts or porters [35]. Keeping in mind the size of the global beer production, almost 12 million tonnes of brewers' spent grain is generated worldwide. The biggest producer, China, accounts for over 2.3 million tonnes, followed by the USA with 1.3 million tonnes, while European production generates around 2.6 million tonnes of BSG [34].

\subsubsection{Composition}

One of the main drawbacks of BSG as a potential raw material for other processes is its high moisture content, exceeding 75\% [36]. Together with the presence of polysaccharides, this factor makes the BSG a perishable material. Drying of brewers' spent grain, which could be easily performed using conventional dryers, might noticeably enhance its attractiveness for other industry branches, including polymer technology [37]. Moreover, BSG is characterized by the relatively low activation energy values during drying, comparable to 
other food industry by-products such as carrots, beans, or general vegetable waste [38]. The drying of BSG requires less energy than, e.g., olive processing by-products, probably due to their high lipid content [38].

The brewers' spent grain can be characterized by a similar composition to various lignocellulose materials except for the high moisture content. As presented in Table 1, the total content of carbohydrates in BSG is around $50 \%$, which is noticeably lower compared to other lignocellulose waste materials, e.g., barley straw (56\%) [39], rye, or oat straw (66-68\%) [40], sunflower or cotton stalks (72-73\%) [40]. Such a phenomenon is attributed to the partial reduction of carbohydrate content during mashing when starch is removed [41].

Moreover, brewers' spent grain contains from 10 to even $28 \%$ of lignin, depending on the reports [48] and a significant amount of proteins, which is attributed to their high content in barley grain [52]. The detailed composition of proteins in BSG may differ depending on the determination method, source of by-product, and applied malts, mostly crop species [33]. According to Robertson et al. [53], the glutamine is the primary amino acid of BSG (around 19-20\% of total proteins), followed by a proline ( $9 \%)$, asparagine, and leucine (both $\sim 8 \%$ ), arginine, phenylalanine, and valine ( $7 \%)$. On the other hand, Waters et al. [54] reported that histidine is present in the highest amount exceeding $26 \%$ of total proteins, followed by glutamine $(\sim 16 \%)$, lysine $(\sim 14 \%)$, and leucine $(\sim 6 \%)$, while the content of other amino acids does not exceed 5\%. Nevertheless, irrespectively of the detailed composition of amino acids, BSG should be considered as protein-rich material.

Brewers' spent grain often contains noticeable amounts of phenolics, which may provide additional value for various applications due to their antioxidant and antimicrobial properties [55]. The main phenolic components of BSG are hydroxycinnamic acids (HCAs) and hydroxybenzoic acids (HBAs), particularly ferulic, $p$-coumaric, sinapic, syringic, and caffeic acids [56-58]. The first two compounds are present in the highest amounts, but the literature reports indicate that their contents depend strongly on the type of malts used for brewing [59]. McCarthy et al. [59] showed that the roasting of pale barley malt reduced the total HCAs content in BSG by 57\%. Also, Moreira et al. [60] pointed to the reduction in total phenolic content due to increasing malt kilning temperature. For chocolate and black malts, kilned at temperatures exceeding $220{ }^{\circ} \mathrm{C}$, the content of ferulic and $p$-coumaric acids was reduced by over $50 \%$. The effect was significantly smaller for melanoidin and carared malts, which were subjected to a temperature in the range of $120-160{ }^{\circ} \mathrm{C}$.

Generally, the structures of the major phenolic acids present in brewers' spent grain are presented in Fig. 3. Their detailed composition in particular BSG samples and other by-products, may noticeably differ depending on the method of their extraction, selection of solvents, and method of the quantitative analysis [35]. Nevertheless, despite the differences in reported contents of HCAs and other phenolics, they significantly enhance the antioxidant activity of BSG compared to other lignocellulose materials.

These compounds mentioned above present in BSG are considered strong antioxidants and may enhance the stability of polymeric materials [61-63]. Considering the antioxidant activity of BSG, it may contain noticeable amounts of melanoidins, mainly when it originated from the production of darker beers. Melanoidins are generated during Maillard<smiles>COc1cc(/C=C/C(=O)O)ccc1O</smiles><smiles>O=C(O)/C=C/c1ccc(O)cc1</smiles>

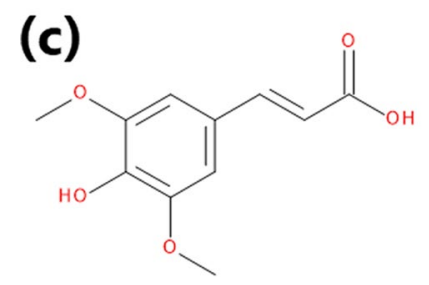

(d)

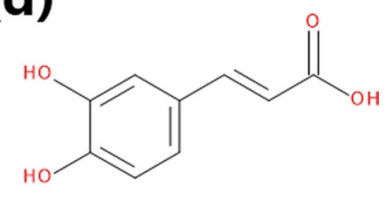

Fig. 3 The structures of the major phenolics of BSG: a ferulic, b $p$-coumaric, $\mathbf{c}$ sinapic, and $\mathbf{d}$ caffeic acid
Table 1 The composition of brewers' spent grain according to the literature reports

\begin{tabular}{lllllllllllll}
\hline Component & \multicolumn{10}{l}{ Content, \%dry matter } \\
\hline Cellulose & - & - & - & 25.4 & $23.0-25.0$ & 16.8 & 22.2 & $12.0-25.0$ & 21.9 & 12.0 & 21.7 \\
Hemicellulose & - & - & - & - & $30.0-35.0$ & 28.4 & 26.8 & $20.0-25.0$ & 29.6 & 40.0 & 19.2 \\
Lignin & - & - & - & 11.9 & - & 27.8 & 14.1 & $10.0-28.0$ & 21.7 & 11.5 & 19.4 \\
Ash & 3.8 & 3.4 & 3.3 & 2.4 & $4.0-4.5$ & 4.6 & - & $2.0-5.0$ & 1.2 & 3.3 & 4.2 \\
Proteins & 26.9 & $21.8-26.4$ & 26.7 & 24.0 & $19.0-23.0$ & 15.3 & - & $19.0-30.0$ & 24.6 & 14.2 & 24.7 \\
Fat & - & $3.6-5.8$ & - & 10.6 & - & - & - & 10.0 & - & 13.0 & - \\
Phenolics & - & $1.6-2.0$ & - & - & - & - & - & - & - & 2.0 & - \\
Reference & 42 & 43 & 44 & 45 & 46 & 47 & 41 & 48 & 49 & 50 & 51 \\
\hline
\end{tabular}


reactions occurring between carbonyl groups of reducing sugars and amino groups of amino acids present in proteins [64]. As a result, the complex mixture of higher molecular weight oligomeric and polymeric compounds is obtained [65]. They are responsible for the browning reactions of various food products after applying temperature, e.g., during baking, frying, or cooking [66].

Moreover, the brewers' spent grain contains multiple micro- and macroelements, mostly silicon, phosphorous, calcium, and magnesium [32]. Combining their content with the presence of vitamins, primarily B3, B4, and B5, the BSG is often investigated in food additives $[48,67]$.

\subsubsection{Current applications and potential in polymer technology}

Animal feed Nowadays, the main application of brewers' spent grain is low-value animal feed with relatively low market value. It is often sold to farmers, mainly in a wet state [68]. It is associated with the composition of this by-product, particularly protein content [45]. As a result, Belibasakis and Tsirgogianni [69] and Sawadogo et al. [70] reported the enhanced milk production for cows fed with BSG. Also, other works reported the beneficial impact on animal nutrition, including fish, pigs, and chickens [71-73]. In the case of lack of potential recipients of BSG for animal feed, this by-product may be deposited in the fields, where in moderate amounts, it can act as natural fertilizer [55].

Human food Considering the nutrition, brewers' spent grain was also investigated as a human food ingredient. Because of its composition and origin, it was introduced into bakery products as a flour substitute [74]. Ground BSG is characterized by a darker color than the lightest types of flour, so it could not be applied in white bread [75]. Nevertheless, BSG showed a very beneficial impact on the bread protein content due to its composition, increasing it by $\sim 50 \%$, when only $10 \%$ of traditional flour was replaced [76]. Combining the protein content with the lack of starch (which is removed during mashing - see Fig. 1), the caloric density of bread containing $10 \%$ of BSG may be even $7 \%$ lower compared to the conventional bread [77]. Except for the bakery products, brewers' spent grain can be incorporated into other highfiber foods [78-81]. In general, the food-sector applications of brewers' spent grain were comprehensively discussed in the excellent review works of McCarthy et al. [82], Lynch et al. [48], and lately Rachwał et al. [83].

Energy production Like other types of waste biomass, BSG was also investigated in energy production, which may be implemented within the brewery, leading to reduced production costs [84]. It can be directly combusted. However, it may cause problems related to the high nitrogen content and resulting generation of nitrogen oxides [85]. Such an effect can be reduced by the application of pyrolysis [86]. Another possibility is converting BSG into charcoal bricks, which increases its calorific value from 20 to $27 \mathrm{MJ} / \mathrm{kg}$ [87, 88]. Multiple works also reported microbial fermentation of brewers' spent grain into bioethanol [89-91] or biogas [92-95], which can be applied as biofuels.

Fermentation Considering fermentation, BSG was investigated as a growth medium [96], e.g., substitute of sucrose or glucose in the lactic fermentation [97-99], medium for pullulan production [100], and introduced into manufacturing of xylitol [101-103] or citric acid [104]. The application of wastes and residues for fermentation is a very common and often investigated approach [105].

Among the mentioned fermentation products, lactic acid is an exciting compound for polymer technology. It is commonly applied in poly(lactic acid) manufacturing-one of the most popular biodegradable, thermoplastic polyesters [106]. Over the last years, it attracted much attention due to the application in 3D printing [107]. Moreover, due to the current law regulations, its popularity in manufacturing packaging materials is increasing, often combined with other, less expensive materials like thermoplastic starch [108].

Except for lactic acid, other BSG fermentation products, which could be applied in polymer technology are citric acid [109] and propionic acid [110]. The first one can be applied as a co-monomer in manufacturing of polyesters [111-114] or as a crosslinking agent $[115,116]$. Propionic acid is a substrate in the production of polymers based on cellulose derivatives, such as cellulose propionate [117]. Their popularity is growing over the last years due to the current proenvironmental trends related to bio-based polymer materials and their potential novel applications, e.g., in 3D printing [118-120].

Figure 4 summarizes the potential applications of BSG fermentation products in polymer technology. Nevertheless, to the best of our knowledge, no works deal with the application of BSG fermentation products in polymer technology. More details related to the recent developments in the biotechnological valorization of these by-products were presented recently in the comprehensive review work by Puligundla and Mok [121].

Extraction of celluloses and lignin Except for the microbial conversion, various compounds present in BSG, which may find application in polymer technology, can be extracted using different techniques [122-124]. Among the most noticeable components of BSG in terms of polymer technology are celluloses and lignin [125]. They could be applied as fillers for composites and intermediates in manufacturing other raw materials used in polymer technology.

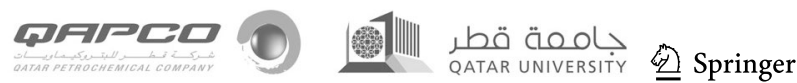




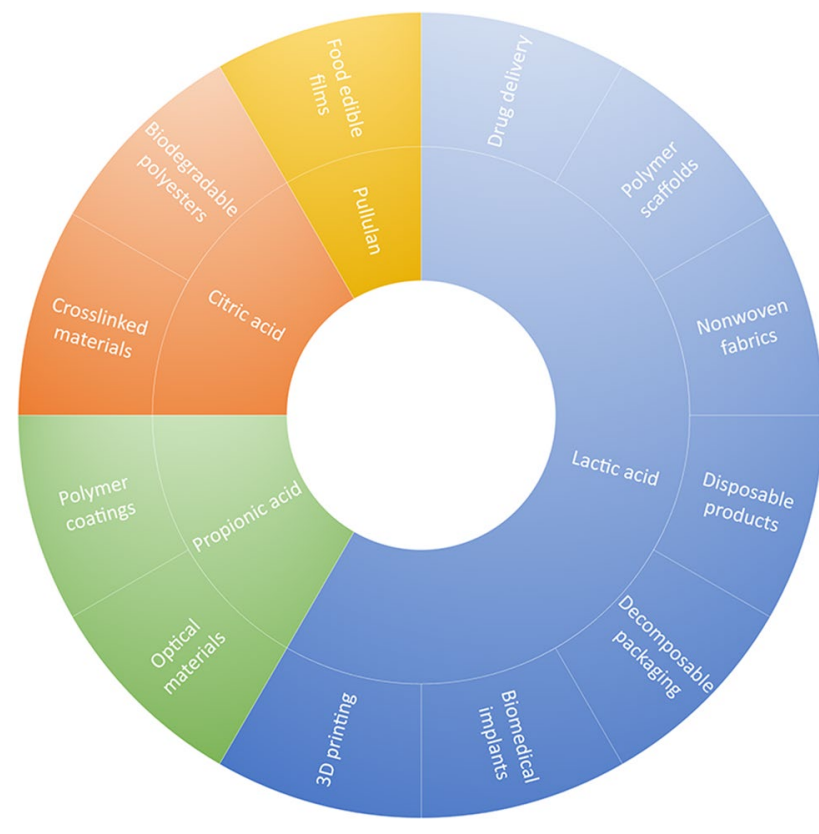

Fig. 4 Potential applications of BSG fermentation products in polymer technology

Mishra et al. [126] presented the multi-stage process of BSG conversion into cellulose nano-fibers consisting of alkali treatments and bleaching. They isolated nanosized fibers with an average diameter of $4.6 \mathrm{~nm}$, shown by atomic force microscopy. Similar fibers are often investigated as fillers for polymer nanocomposites [127-129]. The efficient isolation of fibers and removal of other components of BSG was confirmed by thermogravimetric analysis (lack of decomposition step attributed to the presence of lignin) and X-ray diffractometry (gradual increase in crystallinity index). Similar observations were made by dos Santos et al. [130].

Mussatto et al. [131] investigated the recovery of lignin from BSG. The by-product was subjected to the soda pulping process, comprehensively described in other work [132]. The resulting black liquor was treated with sulfuric acid, which enabled the separation of lignin by precipitation. Except for the lignin, the investigated process enabled the removal of ferulic, $p$-coumaric, $p$-hydroxybenzoic, vanillic, and syringic acids from black liquor. Such an effect points to the presence of these compounds in obtained lignin, which could be applied, e.g., as a filler for wood-polymer composites.

Quite interesting is also the extraction of arabinoxylans from brewers' spent grain. They are hemicelluloses found in plants' primary and secondary cell walls, which consist of copolymers of arabinose and xylose [133]. They play a structural role in plants, and interestingly the significant amounts of phenolic acids are bound to them, so they show noticeable antioxidant activity [134]. Arabinoxylans and their esters are applied in polymer technology to develop biodegradable and even edible films $[135,136]$, which could be efficiently applied in food packaging applications [137-139]. They could be enzymatically extracted from BSG in a multi-step procedure [140-142]. The extraction efficiency can be significantly enhanced by the proper particle size distribution of BSG adjusted by milling and sieving, as proven by Reis et al. [143]. Moreirinha et al. [144] used the brewers' spent grain arabinoxylans to prepare composite films with a different share of nanocellulose. Moreover, selected composite films were modified with ferulic acid or feruloylated arabinoxylo-oligosaccharides obtained from BSG. All prepared films were characterized by the onset of thermal decomposition exceeding typical sterilization or autoclaving temperatures $\sim 150{ }^{\circ} \mathrm{C}$. They were characterized by satisfactory mechanical performance, with Young's modulus in the range of 4.3-7.5 GPa (the highest for composite containing 50\% of nanocellulose) and tensile strength of 71-110 MPa (the highest for $75 \%$ nanocellulose loading). Modifications of films unfavorably affected the mechanical performance but increased the antioxidant activity determined by DPPH assay from the initial $2 \%$ to $64-90 \%$. Also, a noticeable reduction in bacterial (Staphylococcus aureus) and fungal (Candida albicans) growth is beneficial for the potential applications in food packaging.

Extraction of phenolics Except for cellulose, hemicellulose, or lignin, also other compounds can be extracted and isolated from brewers' spent grain. Very auspicious are the phenolics mentioned above, primarily hydroxycinnamic acids, showing antioxidant properties. The BSG should be considered an inexpensive source of these compounds, which could be efficiently applied not only in the food or cosmetic industry [145-147] but also as potential antioxidants for polymer materials [148-150]. Phenolics can be recovered from brewers' spent grain by different variants of extraction, e.g., solid-liquid type or assisted by supercritical fluids, microwaves or ultrasounds, and enzymatic or alkaline reactions [151-153]. As mentioned above, the yield of their recovery strongly depends on the extraction method and its parameters, e.g., selected solvents [154]. Similar phenomena were reported for other by-products, e.g., from the coffee industry, also characterized by high phenolics content [155-157]. The recent advances in the extraction of bioactive compounds, including phenolics, from brewers' spent grain, were comprehensively summarized in the excellent work of Bonifácio-Lopes et al. [158]. Nevertheless, to the best of our knowledge, there are no literature works reporting the application of BSG-originated phenolics in polymer materials.

Liquefaction Considering other, more direct uses of brewers' spent grain in polymer technology, in our previous 
work [159], we used the brewers' spent grain as a biomass feedstock for crude glycerol-based microwave liquefaction aimed at manufacturing biopolyols for polyurethanes. The general scheme of the process is presented in Fig. 5. The spectroscopic investigation of obtained polyols revealed that biomass was partially decomposed during the process and reacted with solvent particles. Nevertheless, the efficiency of the process was relatively low, and the hydroxyl values were in the range of $900-1050 \mathrm{mg} \mathrm{KOH} / \mathrm{g}$. Such values are very high and could be suitable only for manufacturing very crosslinked and stiff materials. Further studies should include the application of catalysts and optimization of process conditions to enhance its efficiency.

Filler for polymer composites On the other hand, the relatively high fiber content in brewers' spent grain makes it attractive for the preparation of wood-polymer composites, possibly applied in various branches of industry [160]. Other fillers, either conventionally applied wood flour or wastebased, are characterized by a relatively similar composition $[161,162]$. Moreover, the presence of proteins, which may act as plasticizers, may facilitate the melt processing of composites [163].

Revert et al. [164] introduced the BSG as a filler into the polypropylene matrix. Nevertheless, due to the polarity differences between filler and matrix, the interfacial interactions were fragile, and the significant deterioration of mechanical performance was noted. The only positive effect of the BSG incorporation was the shift of the oxidation onset temperature attributed to the presence of phenolics showing antioxidant activity. The addition of $10-40 \mathrm{wt} \%$ of byproduct shifted the oxidation onset by $10-23{ }^{\circ} \mathrm{C}$.

Barbu et al. [165] introduced BSG into particleboards as a partial replacement of wood, which is a common trend in the case of wood-polymer composites [166-168]. The appearance of BSG without additional treatment (presented in Fig. 6) is quite similar to the wood chips, so this by-product can be easily applied as substitute for conventional raw materials. Particleboards bonded with polymeric 4,4'-methylene diphenyl isocyanate, urea-formaldehyde, or melamine urea-formaldehyde resin. Nevertheless, according to the presented results, to maintain the satisfactory level of the mechanical properties, the content of BSG should be kept at low levels (up to 10\%). The structural differences associated with the reduction in particle-particle bonding between wood particles were noted at higher loadings due to the high consumption of glue by BSG. Authors suggested that at higher contents, brewers' spent grain should be combined with innovative glues, based on casein or tannins, which could improve the particle-particle bonding. Similar conclusions about the potential, beneficial share of BSG in wood-based particleboards were provided by Klimek et al. [169], who also suggested the $10 \%$ substitution of wood with BSG.

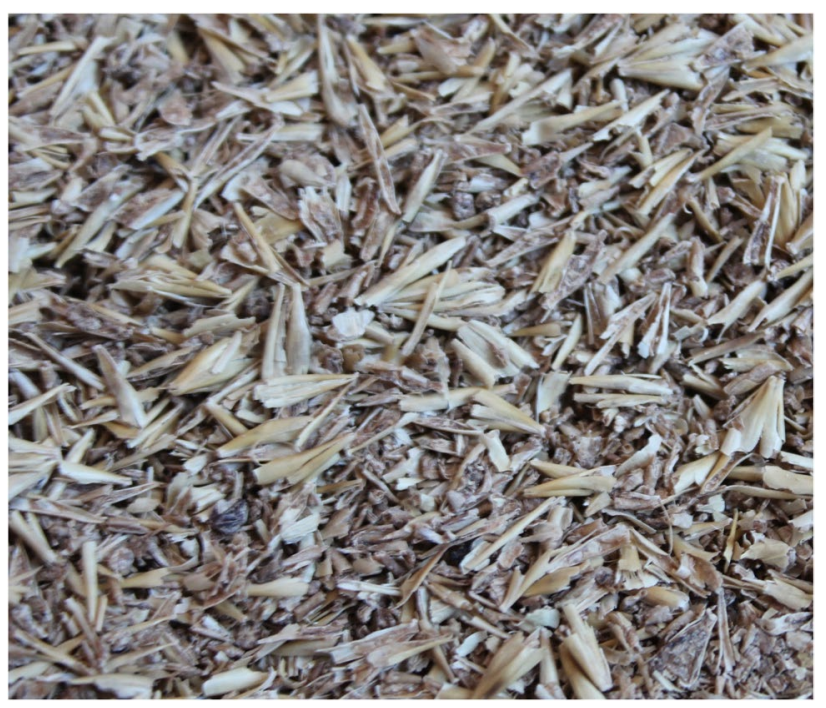

Fig. 6 The appearance of BSG without additional treatment
Fig. 5 The general scheme of microwave-assisted liquefaction of BSG resulting in biopolyol for polyurethanes [159]

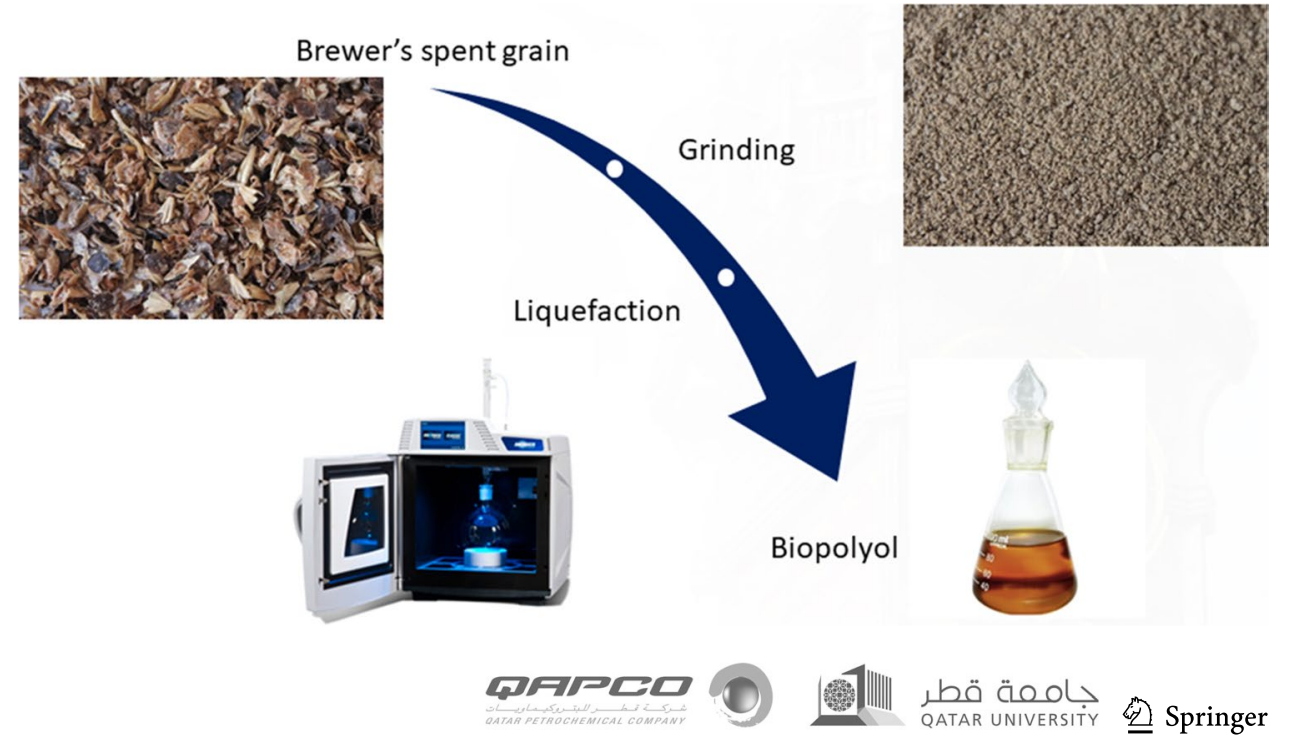


A very interesting application of BSG in polymer technology was also presented by Ferreira et al. [170], who used it to prepare disposable trays for food packaging. They were obtained by compression molding of BSG with potato starch applied as a continuous phase. The process was aided with the addition of glycerol, water, and in some cases gelatin, chitosan, or glyoxal applied as crosslinkers. After compression, trays were covered with beeswax. Obtained materials were characterized by significantly higher flexural strength and modulus than commercial trays from expanded polystyrene. Independently of the BSG content (from 20 to $80 \%$ in the whole tray), trays showed strength in the range of 1.51-2.62 MPa, compared to the $0.64 \mathrm{MPa}$ for commercial material. Also, the modulus was noticeably higher (1.12.0 MPa) compared to polystyrene trays $(0.28 \mathrm{MPa})$. Nevertheless, due to their composition and hydrophilic character of applied raw materials, trays showed significantly higher water absorption than polystyrene, which resulted in a significant $80-90 \%$ decrease in mechanical parameters. Such an effect was attributed to the plasticizing effect of water. The application of crosslinkers or beeswax slightly reduced the water absorption. However, deterioration was still noted after immersion, and polystyrene trays showed noticeably superior properties. Nevertheless, presented results indicate that such a solution is quite promising, especially for applications that do not require exceptional resistance to water.

Generally, multiple works dealing with the application of brewers' spent grain in the polymer sector, especially these dealing with its use as a filler for composites or substitute of wood in particleboards, indicate the necessity for modifying this by-product $[171,172]$. Modifications should be aimed at enhancing the interfacial interactions with polymer matrices by the change of their hydrophilic character. Such an effect could be achieved by thermo-mechanical treatment resulting in non-enzymatic browning in the caramelization process and mostly Maillard reactions, as presented in our previous works $[34,173]$. It is also essential that melanoidins show noticeable antioxidant activity, which can be very beneficial for the oxidative stability of polymer composites [174].

In previous works, we reported the application of thermomechanically modified BSG as a potential filler for woodpolymer composites $[175,176]$.

In the case of poly( $\varepsilon$-caprolactone) composites, their mechanical performance was noticeably affected by the parameters of thermo-mechanical treatment of BSG [175]. The increase of modification temperature noticeably affected the interface surface area, resulting in an even $30 \%$ increase in composites' toughness. Dynamic mechanical analysis indicated over 30\% drop in the adhesion factor and increased the constrained chain volume exceeding $27 \%$. Such an effect points to the significant enhancement of the interfacial interactions.
On the other hand, modified BSG could be effectively applied to substitute traditional wood flour in polyethylenebased composites [176]. Nevertheless, due to the differences in the chemical composition between fillers (presence of proteins, lipids, and melanoidins in BSG, lower content of holocellulose compared to wood flour), the composites' performance was differing. The introduction of BSG resulted in significantly higher values of melt flow index. When wood flour was completely substituted, it increased from 3.23 to $10.56 \mathrm{~g} / 10 \mathrm{~min}$, which was attributed to the drop in viscosity from 1.02 to $0.30 \mathrm{~Pa}$ s. A similar effect was noted in our other work [163]. The density and porosity of materials were slightly reduced with the increasing share of BSG due to the presence of proteins, which may enable better encapsulation of filler particles with polymer macromolecules. However, it also caused changes in the composites' mechanical performance. Tensile strength and modulus were reduced by 27\% and $\sim 42 \%$, respectively, but the elongation at break was doubled. Concluding, modified brewers' spent grain could be introduced as partial replacement of conventional wood flour to engineer materials with desired properties.

Others Other, less popular methods of BSG utilization include the manufacturing of adsorbents [177-179], paper [47, 180], bricks [87], or activated carbon [181]. Brewers' spent grain-based adsorbents, and activated carbons were found efficient in the removal of dyes [182-185], volatile organic compounds from the gas phase [186], but mostly metal ions from aqueous media [187-191].

\subsection{Trub, spent hops}

\subsubsection{Overview}

Trub is generated during filtration of wort before the fermentation. After cooling down, the wort is separated from the trub, accounting for around $0.2-0.4 \%$ of the wort volume [28]. The precipitate contains coagulates of high molecular weight proteins [192]. They are generated during the heat-induced denaturation of proteins. Except for coagulates, the residual hops may be present in trub, because according to the literature data, around $85 \%$ of the initial hops mass introduced into wort is removed as a byproduct [77]. After extracting the compounds that create the flavor, aroma, and bitterness of the final beer, the solid residues of hops are discarded. However, their content in trub depends on the applied technology of beer hopping [193]. Therefore, the composition of this by-product may be very diverse, depending on the share of coagulates and spent hops. 


\subsubsection{Composition}

Separately, trub contains mostly significant amounts of proteins, even up to $70 \%$ of dry matter [83]. Considering spent hops, the proteins account for around 22-23\% of dry matter, with a similar share of fiber [194]. According to Mathias et al. [42], around $20 \%$ of the residual reducing sugars may also be present in trub. Both trub and spent hops contain relatively low amounts of ash, $2 \%$, and $\sim 6 \%$, respectively. Interestingly, this by-product may contain noticeable amounts of essential oils and phenolics due to the hop presence. Such an effect is attributed to the low solubility of various compounds in the wort, e.g., in the case of lupulones [195]. On the other hand, phenolics such as hydroxycinnamic acids, gallic acid, catechins, anthocyanidines, and others, are precipitated with proteins and removed as a part of hot trub [196]. The essential oils contain noticeable amounts of terpenes [67]. Moreover, myrcene, alpha-humulene, or beta-ceryophyllene are present. They account for $\sim 47 \%$ of the essential oil [197]. The structures of main components of essential oils are presented in Fig. 7.

\subsubsection{Current applications and potential in polymer technology}

Contrary to the brewers' spent grain, the trub and spent hops are significantly less frequently used in animal feeding, despite the beneficial composition, relatively high fiber content, and mostly the presence of proteins. Such an effect is attributed to the presence of hops, particularly bitterness [198]. Another issue is the low energy value of spent hops, which is around 50\% lower than spent grains, despite the relatively high fiber content [77]. On the other hand, some research works investigated the combination of spent hops

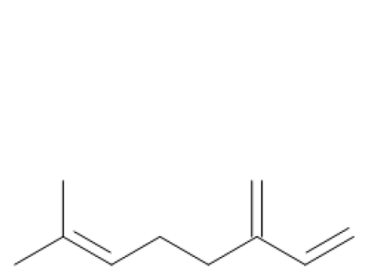

(a)

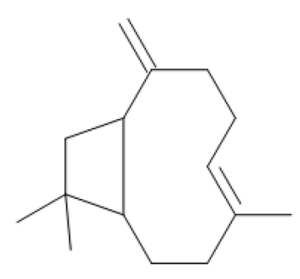

(c)

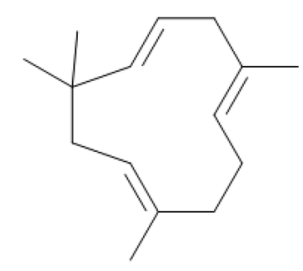

(b)

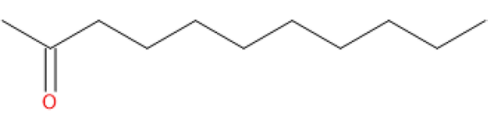

(d)
Fig. 7 The main components of spent hops essential oil: a myrcene, $\mathbf{b}$ $\alpha$-humulene, $\mathbf{c} \beta$-caryophyllene, and d 2-undecanone [197] with other brewery by-products, which resulted in acceptable feed, e.g., for pigs [199]. According to the works of Huszcza et al. [200, 201], the bitter acids originated from spent hops can be removed or degraded by yeast or fungi. More recent works dealing with the trub and spent hops investigated the reduction of bitterness by the multi-step extraction of bitter compounds [202]. During extraction, most carbohydrates were removed together with tannins and phenolics, which are often bound to the carbohydrates. As a result, the share of proteins and fat was increased from the initial $26.5 \%$ and $5.2 \%$ to $70.3 \%$ and $9.9 \%$, respectively. Due to the significant drop of phenolics content (from 350 to $125 \mathrm{mg}$ gallic acid equivalents $/ 100 \mathrm{~g}$ ), the antioxidant activity was also noticeably reduced. Nevertheless, changes resulting from the extraction allowed the use of modified trub in food applications.

Considering the most popular uses of biomass and brewery by-products, except for the animal feed, trub and spent hops may be applied as a soil conditioner and fertilizer, which is associated with their high nitrogen content [42, 203].

As mentioned above, the trub and spent hops contain noticeable amounts of essential oils and phenolics. These compounds can be effectively extracted from this by-product and potentially applied in polymer technology. Bedini et al. [197] reported that the terpenes present in spent hops could be applied as the repellents against the insects, e.g., Rhyzopertha dominica or Sitophilus granarius. Spent hops essential oils were 2-5 times more effective against $R$. dominica than Laurus nobilis oils [204] and showed similar repellency against $S$. granaries as Hyptis suaveolens oils [205]. Bartmańska et al. [206] also showed antifungal activity of spent hops extracts against Botrytis cinerea, Fusarium oxysporum, Fusarium culmorum, and Fusarium semitectum. Therefore, the application of spent hops or only their essential oils in manufacturing the packaging materials seems reasonable. The extraction and isolation of essential oils from spent hops can be performed by hydrolysis, steam distillation, but also using supercritical $\mathrm{CO}_{2}$ or eutectic solvents [207-210].

Moreover, this by-product can be applied in fermentation processes as a supplement for microbes due to the high nitrogen content [83] and the presence of lipids and zinc [211].

\subsection{Spent yeast}

\subsubsection{Overview}

During the initial stage of fermentation, the intensive proliferation of yeast is occurring, so after fermentation and maturation, the surplus of yeast is present and should be removed from beer [212]. Partially, they are recovered by natural sedimentation, but for higher efficiency, additional

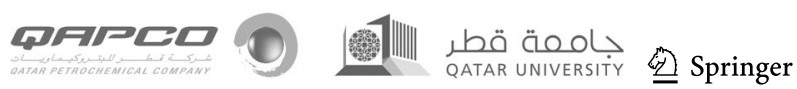


filtration or centrifugation may be applied [213]. The actual amount of this by-product depends on the type of yeast used for fermentation, but it can account even for $15 \%$ of total by-products generated during beer production [214]. Around $0.3 \mathrm{~kg}$ of spent yeast is generated per hectoliter of beer. Depending on the properties of yeast, in particular their flocculation, this by-product is characterized by the high moisture content in the range of $75-90 \%$. Therefore, portion of beer is removed along with yeast, which may generate the $1.5-3.0 \%$ loss of beer [28].

\subsection{Composition}

Considering the composition, spent yeast contains a noticeable amount of carbohydrates and proteins. Among the first group, the most abundant are non-cellulose compounds (25-35\%), mainly $\beta$-glucans, mannoproteins, and glycogen, followed by cellulose (17-25\%) [215]. Proteins may account for more than $50 \%$ of the spent yeast dry mass [195, 216]. Jacob et al. [217] reported even value of 74.3 $w t \%$. Therefore, the spent yeast is characterized by the lowest carbon:nitrogen ratio among the brewing by-products, around 5 [42]. Literature works report different amino acid compositions of spent yeast. According to Vieira et al. [218], the most common amino acids in spent yeast are alanine (even over 9\%), arginine, aspartic acid, and cysteine. At the same time, Jaeger et al. [219] indicated that glutamic acid is the most abundant one $(\sim 15 \%)$, followed by histidine, alanine, arginine, and aspartic acid. Such an effect may be associated with the differences between particular Saccharomyces cerevisae strains applied worldwide [220].

Brewery spent yeast are also a great source of micro- and macroelements, as well as vitamins. Nevertheless, the mineral composition of yeast can differ depending on the length of fermentation and fermentation cycles [67]. Among the most abundant minerals are sodium, potassium, and magnesium, but noticeable amounts of phosphorous may be present, which could be associated with yeast nutrients in breweries [195]. Considering the vitamins, the B type is the most popular, especially niacin, thiamin, pantothenate, and riboflavin [218].

\subsubsection{Current applications and potential in polymer technology}

Due to the high content of proteins, vitamins, and minerals, the spent yeast is mostly applied as an additive in animal feeding [221]. It has been repeatedly proven that such application of this by-product shows very positive effects on the animals' health. It may result in increased milk production, improved microflora, and enhanced resistance to various microorganisms [222-224]. Except for the animal feed, spent yeast was also investigated in human consumption. However, they show great potential due to the high contents of nucleic acids (6-15\%), in particular ribonucleic acid, their use in an unmodified state is somewhat limited [216]. The ribonucleic acid is metabolized to the uric acid in the human body, which can cause gout [225]. Generally, the spent yeast application in animal and human nutrition was comprehensively discussed in dedicated review works [219, 226-229].

Another broadly investigated application of spent yeast is cultivating microorganisms and other biotechnological processes [230, 231]. Due to the beneficial composition of brewery spent yeast, various microorganisms cultivated on this by-product may grow noticeably faster than other yeast types, as reported by Ferreira et al. [232]. As a result, the spent yeast may be applied as a very efficient source of multiple enzymes, including proteinases [233], proteases [234, 235], or pectinases [236, 237]. Moreover, brewery spent yeast can be applied as nutrients during ethanol or lactic acid fermentation [238, 239]. Pietrzak and KawaRygielska [240] showed that the 5\% addition of brewery spent yeast might increase the rate of sugar consumption and ethanol production resulting in even $11 \%$ enhancement of ethanol yield. Such an effect was ascribed to the high nitrogen content of the medium.

Other, less popular uses of spent yeast from beer production include methane production or application as biosorbent. Considering the energy production, spent yeast can be considered an excellent substrate for co-digestion purposes with other materials, including swine manure [241], spent grains [242], or crude glycerol [243].

Considering the polymer technology point of view, the brewery spent yeast show hardly any applications. The most promising and the closest to polymer technology is their use in fermentation processes generating lactic or succinic acid. The use of lactic acid in polymer technology was described in Sect. 3.1.3. The succinic acid can be applied in the manufacturing of polyesters or alkyd resins [244, 245].

Rakin et al. [246] reported that the application of spent yeast might increase the rate and yield of lactic acid fermentation due to the presence of amino acids, vitamins, and minerals. Similar observations were made by Champagne et al. [247]. According to Radosavljević et al. [248], the brewery spent yeast, combined even with other brewery by-products, can act as a low-cost fermentation medium for manufacturing of lactic acid.

Considering succinic acid production, the substitution of conventional yeast extracts with hydrolysate of spent brewery yeast as a nitrogen source was successfully achieved by Jiang et al. [249] and Chen et al. [250].

Nevertheless, to the best of our knowledge, there are no literature reports directly connecting the brewery spent yeast with the polymer technology. 


\section{Conclusions, future trends, and developments}

The presented review summarized the literature works associated with the by-products of beer production. Their generation during brewing was discussed, and the beer market size, which affects the amount of by-products. Reported data about the composition of brewers' spent grain, trub, spent hops, and spent yeast indicate that the application in polymer technology should be considered an auspicious method of their utilization, viable from the ecological and economic point of view. Moreover, their chemical composition, particularly the presence of compounds showing antimicrobial, antifungal and antioxidant activity, puts the brewing by-products as potential active fillers providing additional properties to polymer materials and promising intermediates in manufacturing various raw materials for polymer technology.

In order to take full advantage of the brewing by-products potential in polymer technology, future works should focus on the following issues:

- Partial substitution of conventional lignocellulosic fillers in wood-polymer composites with brewers' spent grain, which could enhance the resistance to thermooxidation.

- Investigations related to the mechanisms of the enhancement of thermooxidative stability of various polymer materials by antioxidants present in brewing by-products.

- The applications of brewing by-products in packaging materials or even edible films for food protection.

- Liquefaction of brewing by-products resulting in raw materials for manufacturing of polyurethanes or polyester resins.

Funding This work was supported by the National Science Centre (NCN, Poland) in the frame of SONATINA 2 project 2018/28/C/ ST8/00187-Structure and properties of lignocellulosic fillers modified in situ during reactive extrusion.

\section{Declarations}

Competing interest The author declares no competing interests.

Open Access This article is licensed under a Creative Commons Attribution 4.0 International License, which permits use, sharing, adaptation, distribution and reproduction in any medium or format, as long as you give appropriate credit to the original author(s) and the source, provide a link to the Creative Commons licence, and indicate if changes were made. The images or other third party material in this article are included in the article's Creative Commons licence, unless indicated otherwise in a credit line to the material. If material is not included in the article's Creative Commons licence and your intended use is not permitted by statutory regulation or exceeds the permitted use, you will need to obtain permission directly from the copyright holder. To view a copy of this licence, visit http://creativecommons.org/licenses/by/4.0/.

\section{References}

1. K.E. Behre, The history of beer additives in Europe-a review. Veg. Hist. Archaeobot. 8(1-2), 35-48 (1999). https://doi.org/ $10.1007 / b f 02042841$

2. R.W. Unger, A History of Brewing in Holland, 900-1900. (Leiden, Brill, The Netherlands, 2001).

3. A. Smejtková, P. Vaculík, M. Přikryl, Z. Pastorek, Rating of malt grist fineness with respect to the used grinding equipment. Res. Agr. Eng. 62(3), 141-146 (2016). https://doi.org/ 10.17221/41/2015-rae

4. F.S. De Almeida, C.A. de AndradeSilva, S.M. Lima, Y.R. Suarez, L.H. da CunhaAndrade, Use of Fourier transform infrared spectroscopy to monitor sugars in the beer mashing process. Food Chem. 263, 112-118 (2018). https://doi.org/10. 1016/j.foodchem.2018.04.109

5. B.V. Humia, K.S. Santos, J.K. Schneider, I.L. Leal, G de Abreu Barreto, T Batista, BA Souza Machado, JI Druzian, LC Krause, M de Costa Mendonca, FF Padilha, Physicochemical and sensory profile of Beauregard sweet potato beer. Food Chem. 312, 126087 (2020). https://doi.org/10.1016/j.foodchem.2019. 126087

6. S. Violino, S. Figorilli, C. Costa, F. Pallottino, Internet of beer: a review on smart technologies from mash to pint. Foods $\mathbf{9 ,} 950$ (2020). https://doi.org/10.3390/foods9070950

7. R. Ravindran, S. Jaiswal, N. Abu-Ghannam, A.K. Jaiswal, A comparative analysis of pretreatment strategies on the properties and hydrolysis of brewers' spent grain. Bioresource Technol. 248, 272-279 (2018). https://doi.org/10.1016/j.biortech.2017.06. 039

8. D. De Keukeleire, Fundamentals of beer and hop chemistry. Quím. Nova 23(1), 108-112 (2000). https://doi.org/10.1590/ s0100-40422000000100019

9. M. Hellwig, S. Witte, T. Henle, Free and protein-bound maillard reaction products in beer: method development and a survey of different beer types. J. Agr. Food Chem. 64(38), 7234-7243 (2016). https://doi.org/10.1021/acs.jafc.6b02649

10. D.O. Schisler, J.J. Ruocco, M.S. Mabee, wort trub content and its effects on fermentation and beer flavor. J. Am. Soc. Brew. Chem. 40(2), 57-61 (1982). https://doi.org/10.1094/asbcj-40-0057

11. D.A. Gee, W.F. Ramirez, A flavour model for beer fermentation. J. I. Brewing 100(5), 321-329 (1994). https://doi.org/10.1002/j. 2050-0416.1994.tb00830.x

12. J. Pasqualino, M. Meneses, F. Castells, The carbon footprint and energy consumption of beverage packaging selection and disposal. J. Food Eng. 103(4), 357-365 (2011). https://doi.org/10. 1016/j.jfoodeng.2010.11.005

13. Statista.com, Beer production worldwide from 1998 to 2019 (in billion hectoliters), https://www.statista.com/statistics/270275/ worldwide-beer-production. Accessed 01 June 2021.

14. Statista.com, Beer production worldwide in 2019 , by region (in million hectoliters), https://www.statista.com/statistics/202417/ beer-output-volumes-of-the-different-continents-in-2010. Accessed 01 June 2021.

15. Statista.com, Leading countries in beer production in the Americas in 2019 (in million hectoliters), https://www.statista.com/ statistics/202409/beer-production-in-different-american-count ries-in-2010. Accessed 01 June 2021. 
16. The Brewers of Europe, European Beer Trends. Statistic Report, 2020 Edition, https://brewersofeurope.org/uploads/mycms-files/ documents/publications/2020/european-beer-trends-2020.pdf. Accessed 01 June 2021.

17. Statista.com, Ranking of the most popular beer types in Germany from 2017 to 2020, https://www.statista.com/statistics/575329/ popular-beer-brands-germany. Accessed 01 June 2021.

18. Statista.com, Volume of beer produced in Europe in 2019, by country (in 1,000 hectoliters), https://www.statista.com/statistics/ 444575/european-beer-production-by-country. Accessed 01 June 2021.

19. Statista.com, Leading 10 countries in beer production of Europe in 2019 (in million hectoliters), https://www.statista.com/stati stics/202400/beer-production-in-europe-in-2010. Accessed 01 June 2021.

20. USA Beer Ratings, Top 10 beer producing countries, https:// usabeerratings.com/en/blog/insights-1/top-10-beer-producingcountries-78.htm. Accessed 01 June 2021.

21. S. Wunderlich, W. Back, Overview of manufacturing beer: ingredients, processes, and quality criteria, in beer in health and disease prevention, $1^{\text {st }}$ Edition, ed. By V. Preedy (Academic Press, Cambridge, USA, 2008), pp. 3-16 (2009). https://doi.org/10. 1016/b978-0-12-373891-2.00001-8

22. D. Brandauer, Food quality, in history - the genesis of the Bavarian Purity Law (beer) from 1516 until today, in Food Security, Food Safety, Food Quality. ed. by I. Hartel, R. Budzinowski (Nomos Verlagsges Mbh \& Co KG, Baden-Baden, Germany, 2016), pp. 153-164

23. W.J.W. Lloyd, Adjuncts. J. I. Brewing 92(4), 336-345 (1986). https://doi.org/10.1002/j.2050-0416.1986.tb04420.x

24. K.S. Mallawarachchi, L.R.L.M. Bandara, S.K.D.H.S. Dilshan, T.U. Ariyadasa, S.H.P. Gunawardena, Optimization of mashing process in beer production using rice as an adjunct. 2016 Moratuwa Engineering Research Conference (MERCon, Morutawa, Sri Lanka, 2016), pp. 289-292. https://doi.org/10.1109/MERCon.2016.7480155

25. R.C. Agu, G.H. Palmer, A reassessment of sorghum for lagerbeer brewing. Bioresource Technol. 66(3), 253-261 (1998). https://doi.org/10.1016/s0960-8524(98)00047-9

26. E.J. Lodolo, J.L.F. Kock, B.C. Axcell, M. Brooks, The yeast Saccharomyces cerevisiae - the main character in beer brewing. FEMS Yeast Res. 8(7), 1018-1036 (2008). https://doi.org/10. 1111/j.1567-1364.2008.00433.x

27. O. Oladokun, S. James, T. Cowley, F. Dehrmann, K. Smart, J. Hort, D. Cook, Perceived bitterness character of beer in relation to hop variety and the impact of hop aroma. Food Chem. 230, 215-224 (2017). https://doi.org/10.1016/j.foodchem.2017.03.031

28. A.A. Olajire, The brewing industry and environmental challenges. J. Clean. Prod. 256, 102817 (2020). https://doi.org/10. 1016/j.jclepro.2012.03.003

29. M. Batayneh, I. Marie, I. Asi, Use of selected waste materials in concrete mixes. Waste Manage. 27(12), 1870-1876 (2007). https://doi.org/10.1016/j.wasman.2006.07.026

30. H. Nakajima, P. Dijkstra, K. Loos, The recent developments in biobased polymers toward general and engineering applications: polymers that are upgraded from biodegradable polymers, analogous to petroleum-derived polymers, and newly developed. Polymers 9, 523 (2017). https://doi.org/10.3390/polym9100523

31. L. Dessbesell, M. Paleologou, M. Leitch, R. Pulkki, C. Xu, Global lignin supply overview and kraft lignin potential as an alternative for petroleum-based polymers. Renew. Sust. Energ. Rev. 123, 109768 (2020). https://doi.org/10.1016/j.rser.2020. 109768

32. S. Ikram, L. Huang, H. Zhang, J. Wang, M. Yin, Composition and Nutrient Value Proposition of Brewers Spent Grain. J. Food
Sci. 82(10), 2232-2242 (2017). https://doi.org/10.1111/17503841.13794

33. C. Wen, J. Zhang, Y. Duan, H. Zhang, H. Ma, A Mini-Review on Brewer's Spent Grain Protein: Isolation, Physicochemical Properties, Application of Protein, and Functional Properties of Hydrolysates. J. Food Sci. 84(12), 3330-3340 (2019). https://doi. org/10.1111/1750-3841.14906

34. A. Hejna, M. Marć, D. Kowalkowska-Zedler, A. Pladzyk, M. Barczewski, Insights into the thermo-mechanical treatment of brewers' spent grain as a potential filler for polymer composites. Polymers 13, 879 (2021). https://doi.org/10.3390/polym13060 879

35. L.F. Guido, M.M. Moreira, Techniques for extraction of brewer's spent grain polyphenols: a review. Food Bioprocess Technol. 10(7), 1192-1209 (2017). https://doi.org/10.1007/ s11947-017-1913-4

36. P. Valverde, Barley spent grain and its future. Cerveza y Malta 122, 7-26 (1994)

37. E. Mallen, V. Najdanovic-Visak, Brewers' spent grains: Drying kinetics and biodiesel production. Bioresource Technol. Report. 1, 16-23 (2018). https://doi.org/10.1016/j.biteb.2018.01.005

38 J.I. Arranz, M.T. Miranda, F.J. Sepúlveda, I. Montero, C.V. Rojas, Analysis of Drying of Brewers' Spent Grain. Proceedings. 2, 1467 (2018). https://doi.org/10.3390/proceedings2231 467

39. R. Slade, A. Bauen, N. Shah, The Commercial Performance of Cellulosic Ethanol Supply-Chains in Europe. Biotechnol. Biofuels 2, 3 (2009). https://doi.org/10.1186/1754-6834-2-3

40. P. Nigam, A. Pandey, Biotechnology for Agro-Industrial Residues Utilisation (Springer, Dordrecht, The Netherlands, 2009)

41. J. Buffington, The economic potential of brewer's spent grain (BSG) as a biomass feedstock. Adv. Chem. Eng. Sci. 4, 308-318 (2014). https://doi.org/10.4236/aces.2014.43034

42. T.R.S. Mathias, V.M.F. Alexandre, M.C. Cammarota, P.P.M. de Mello, E.F.C. Sérvulo, Characterization and determination of brewer's solid wastes composition. J. I. Brewing 121(3), 400-404 (2015). https://doi.org/10.1002/jib.229

43. M. Santos, J. Jiménez, B. Bartolomé, C. Gómez-Cordovés, M. del Nozal, Variability of brewer's spent grain within a brewery. Food Chem. 80(1), 17-21 (2003). https://doi.org/10.1016/s03088146(02)00229-7

44. I. Celus, K. Brijs, J.A. Delcour, The effects of malting and mashing on barley protein extractability. J. Cereal Sci. 44(2), 203-211 (2006). https://doi.org/10.1016/j.jcs.2006.06.003

45. O. Kanauchi, K. Mitsuyama, Y. Araki, Development of a functional germinated barley foodstuff from brewers' spent grain for the treatment of ulcerative colitis. J. Am. Soc. Brew. Chem. 59, 59-62 (2001). https://doi.org/10.1094/ASBCJ-59-0059

46. S. Aliyu, M. Bala, Brewer's spent grain: a review of its potentials and applications. Afr. J. Biotechnol. 10(3), 324-331 (2011). https://doi.org/10.5897/AJBx10.006

47. S.I. Mussatto, G.J.M. Rocha, I.C. Roberto, Hydrogen peroxide bleaching of cellulose pulps obtained from brewer's spent grain. Cellulose 15, 641-649 (2008). https://doi.org/10.1007/ s10570-008-9198-4

48. K.M. Lynch, E.J. Steffen, E.K. Arendt, Brewers' spent grain: a review with an emphasis on food and health. J. I. Brewing 122, 553-568 (2016). https://doi.org/10.1002/jib.363

49. F. Carvalheiro, M. Esteves, J. Parajó, H. Pereira, F. Gırio, Production of oligosaccharides by autohydrolysis of brewery's spent grain. Bioresource Technol. 91, 93-100 (2004). https://doi.org/ 10.1016/S0960-8524(03)00148-2

50. C. Xiros, E. Topakas, P. Katapodis, P. Christakopoulos, Hydrolysis and fermentation of brewer's spent grain by Neurospora crassa. Bioresource Technol. 99, 5427-5435 (2008). https://doi. org/10.1016/j.biortech.2007.11.010 
51. N.G. Meneses, S. Martins, J.A. Teixeira, S.I. Mussatto, Influence of extraction solvents on the recovery of antioxidant phenolic compounds from brewer's spent grains. Sep. Purif. Technol. 108, 152-158 (2013). https://doi.org/10.1016/j.seppur.2013.02.015

52. M. Gupta, N. Abu-Ghannam, E. Gallaghar, Barley for brewing: characteristic changes during malting, brewing and applications of its by-products. Compr. Rev. Food Sci. F. 9(3), 318-328 (2010). https://doi.org/10.1111/j.1541-4337.2010.00112.x

53. J.A. Robertson, K.J.A. I'Anson, J. Treimo, C.B. Faulds, T.F. Brocklehurst, V.G.H. Eijsink, K.W. Waldron, Profiling brewers' spent grain for composition and microbial ecology at the site of production. LWT-Food Sci. Technol. 43(6), 890-896 (2010). https://doi.org/10.1016/j.lwt.2010.01.019

54. D.M. Waters, F. Jacob, J. Titze, E.K. Arendt, E. Zannini, Fibre, protein and mineral fortification of wheat bread through milled and fermented brewer's spent grain enrichment. Eur. Food Res. Technol. 235, 767-778 (2012). https://doi.org/10.1007/ s00217-012-1805-9

55. D. Yu, Y. Sun, W. Wang, S.F. O'Keefe, A.P. Neilson, H. Feng, Z. Wang, H. Huang, Recovery of protein hydrolysates from brewer's spent grain using enzyme and ultrasonication. Int. J. Food Sci. Tech. 55, 357-368 (2020). https://doi.org/10.1111/ijfs.14314

56. C.B. Faulds, A.I. Sancho, B. Bartolome, Mono- and dimeric ferulic acid release from brewer's spent grain by fungal feruloyl esterases. Appl Microbiol Biot 60(4), 489-493 (2002). https:// doi.org/10.1007/s00253-002-1140-3

57. D. Szwajgier, A. Wasko, Z. Targonski, M. Niedzwiadek, M. Bancarzewska, The use of a novel ferulic acid esterase from lactobacillus acidophilus K1 for the release of phenolic acids from brewer's spent grain. J. I. Brewing 116(3), 293-303 (2010). https://doi.org/10.1002/j.2050-0416.2010.tb00434.x

58. A.C. Fărcaş, S.A. Socaci, F.V. Dulf, M. Tofană, E. Mudura, Z. Diaconeasa, Volatile profile, fatty acids composition and total phenolics content of brewers' spent grain by-product with potential use in the development of new functional foods. J. Cereal Sci. 64, 34-42 (2015). https://doi.org/10.1016/j.jcs.2015.04.003

59. A.L. McCarthy, Y.C. O'Callaghan, S. Neugart, C.O. Piggott, A. Connolly, M.A.K. Jansen, A. Krumbein, M. Schreiner, R.J. Fitzgerald, N.M. O'Brien, The hydroxycinnamic acid content of barley and brewers' spent grain (BSG) and the potential to incorporate phenolic extracts of BSG as antioxidants into fruit beverages. Food Chem. 141(3), 2567-2574 (2013). https://doi. org/10.1016/j.foodchem.2013.05.048

60. M.M. Moreira, S. Morais, D.O. Carvalho, A.A. Barros, C. Delerue-Matos, L.F. Guido, Brewer's spent grain from different types of malt: Evaluation of the antioxidant activity and identification of the major phenolic compounds. Food Res. Int. 54(1), 382-388 (2013). https://doi.org/10.1016/j.foodres.2013.07.023

61. K. Moraczewski, M. Stepczyńska, R. Malinowski, B. Budner, T. Karasiewicz, B. Jagodziński, Selected properties of polycaprolactone containing natural anti-aging compounds. Adv. Polym. Technol. 37, 3499-3510 (2018). https://doi.org/10.1002/adv. 22134

62. K. Moraczewski, M. Stepczyńska, R. Malinowski, T. Karasiewicz, B. Jagodziński, P. Rytlewski, The Effect of Accelerated Aging on Polylactide Containing Plant Extracts. Polymers 11, 575 (2019). https://doi.org/10.3390/polym11040575

63. K. Moraczewski, M. Stepczyńska, R. Malinowski, B. Budner, T. Karasiewicz, B. Jagodziński, Selected properties of polylactide containing natural antiaging compounds. Polym. Adv. Technol. 29(12), 2963-2971 (2018). https://doi.org/10.1002/pat.4416

64. L.C. Maillard, Action des acides amines sur les sucres; formation de melanoidines par voie méthodique. Compt. Rend. 154, 66-68 (1912)
65. R.C. Borrelli, A. Visconti, C. Mennella, M. Anese, V. Fogliano, Chemical characterization and antioxidant properties of coffee melanoidins. J. Agr. Food Chem. 50(22), 6527-6533 (2002). https://doi.org/10.1021/jf025686o

66. G. Alves, P. Xavier, R. Limoeiro, D. Perrone, Contribution of melanoidins from heat-processed foods to the phenolic compound intake and antioxidant capacity of the Brazilian diet. J. Food Sci. Technol. 57, 3119-3131 (2020). https://doi.org/10. 1007/s13197-020-04346-0

67. A. Karlović, A. Jurić, N. Ćorić, K. Habschied, V. Krstanović, $\mathrm{K}$. Mastanjević, By-products in the malting and brewing industries-re-usage possibilities. Fermentation 6, 82 (2020). https:// doi.org/10.3390/fermentation6030082

68. T.R. Dhiman, H.R. Bingham, H.D. Radloff, Production response of lactating cows fed dried versus wet brewers' grain in diets with similar dry matter content. J. Dairy. Sci. 86, 2914-2921 (2003). https://doi.org/10.3168/jds.S0022-0302(03)73888-0

69. N.G. Belibasakis, D. Tsirgogianni, Effects of wet brewers grains on milk yield, milk composition and blood components of dairy cows in hot weather. Anim. Feed Sci. Tech. 57, 175-181 (1996). https://doi.org/10.1016/0377-8401(95)00860-8

70. L. Sawadogo, H. Sepehri, L.M. Houdebine, Presence of a factor stimulating prolactin and growth hormone secretion in brewers' spent grains. Reprod. Nutr. Dev. 29, 139-146 (1989)

71. T.N.P. Gondwe, J.P. Mtimuni, A.C.L. Safalaoh, Evaluation of brewery by-products replacing vitamin premix in broiler finisher diets. Indian J. Anim. Sci. 69, 347-349 (1999)

72. V.I. Kaur, P.K. Saxena, Incorporation of brewery waste in supplementary feed and its impact on growth in some carps. Bioresource Technol. 91, 101-104 (2004). https://doi.org/10.1016/ S0960-8524(03)00073-7

73. I.D.I. Yaakugh, T.S.B. Tegbe, S.A.S. Olorunju, A.O. Aduku, Replacement value of brewers' dried grain for maize on performance of pigs. J. Sci. Food Agr. 66, 465-471 (1994). https://doi. org/10.1002/jsfa.2740660407

74. A. Ktenioudaki, V. Chaurin, S.F. Reis, E. Gallagher, Brewer's spent grain as a functional ingredient for breadsticks. Int. J. Food. Sci. Technol. 47, 1765-1771 (2012). https://doi.org/10.1111/j. 1365-2621.2012.03032.x

75. M.Z. Miranda, M.V.E. Grossmann, E.H. Nabeshima, Utilization of brewers' spent grain for the production of snacks with fiber. 1. Physicochemical characteristics. Braz. Arch. Biol. Techn. 37, 483-493 (1994)

76. H.Z. Hassona, High fibre bread containing brewer's spent grains and its effect on lipid metabolism in rats. Nahrung 37, 576-582 (1993). https://doi.org/10.1002/food.19930370609

77. N.J. Huige, Brewery by-products and effluents, in Handbook of Brewing, ed. By W.A. Hardwick (Marcel Dekker, New York, USA, 1994) pp. 501-550.

78. E.B. Özvural, H. Vural, I. Gokbulut, O. Ozboy-Ozbas, Utilization of brewer's spent grain in the production of Frankfurters. Int. J. Food Sci. Technol. 44, 1093-1099 (2009). https://doi.org/10. 1111/j.1365-2621.2009.01921.x

79. M. Nagy, C.A. Semeniuc, S.A. Socaci, C.A. Pop, A.M. Rotar, C.D. Salagean, M. Tofana, Utilization of brewer's spent grain and mushrooms in fortification of smoked sausages. Food Sci. Technol. 37, 315-320 (2017). https://doi.org/10.1590/1678-457x. 23816

80. M.S. Choi, Y.S. Choi, H.W. Kim, K.E. Hwang, D.H. Song, S.Y. Lee, C.J. Kim, K. Hwang, D. Song, S. Lee, C. Kim, Effects of replacing pork back fat with brewer's spent grain dietary fiber on quality characteristics of reduced-fat chicken sausages. Food Sci. Animal Res. 34, 158-165 (2014). https://doi.org/10.5851/ kosfa.2014.34.2.158 
81. H. Kim, K. Hwang, D. Song, S. Lee, M. Choi, Y. Lim, J. Choi, Y. Choi, H. Kim, C. Kim, Effects of dietary fiber extracts from brewer's spent grain on quality characteristics of chicken patties cooked in convective oven. J. Am. Soc. Brew. Chem. 33, 45-52 (2013). https://doi.org/10.5851/kosfa.2013.33.1.45

82. A. McCarthy, Y. O'Callaghan, C. Piggott, R. Fitzgerald, N. O'Brien, Brewers' spent grain; bioactivity of phenolic component, its role in animal nutrition and potential for incorporation in functional foods: A review. P. Nutr. Soc. 72(1), 117-125 (2013). https://doi.org/10.1017/S0029665112002820

83. K. Rachwał, A. Waśko, K. Gustaw, M. Polak-Berecka, Utilization of brewery wastes in food industry. PeerJ 8, e9427 (2020). https:// doi.org/10.7717/peerj.9427

84. G. Sperandio, T. Amoriello, K. Carbone, M. Fedrizzi, A. Monteleone, S. Tarangioli, M. Pagano, Increasing the value of spent grains from craft microbreweries for energy purposes. Chem. Engineer. Trans. 58, 487-492 (2017). https://doi.org/10.3303/ CET1758082

85. R. Meyer-Pittroff, Utilization of spent brewers' grain for energy production. Brauwelt 128, 1156-1158 (1988)

86. L.D.M.S. Borel, T.S. Lira, J.A. Ribeiro, C.H. Ataíde, M.A.S. Barrozo, Pyrolysis of brewer's spent grain: Kinetic study and products identification. Ind. Crop. Prod. 121, 388-395 (2018). https://doi.org/10.1016/j.indcrop.2018.05.051

87. W. Russ, H. Mörtel, R. Meyer-Pittroff, Application of spent grains to increase porosity in bricks. Constr. Build. Mater. 19, 117-126 (2005). https://doi.org/10.1016/j.conbuildmat.2004.05. 014

88. H. Okamoto, K. Sato, N. Yagi, M. Inoue, S. Yamasaki, S. Ishida, J. Shibata, Development of production process of charcoal bricks from spent grain. Kagaku Kogaku Ronbun. 28, 137-142 (2002). https://doi.org/10.1252/kakoronbunshu.28.137

89. S. Bedő, M. Rozbach, L. Nagy, A. Fehér, C. Fehér, Optimised Fractionation of Brewer's Spent Grain for a Biorefinery Producing Sugars, Oligosaccharides, and Bioethanol. Processes 9, 366 (2021). https://doi.org/10.3390/pr9020366

90 R. Liguori, C.R. Soccol, L. Porto de Souza Vandenberghe, A.L. Woiciechowski, V. Faraco, Second generation ethanol production from brewers' spent grain. Energies. 8, 2575-2586 (2015). https://doi.org/10.3390/en8042575

91. C. Xiros, P. Christakopoulos, Enhanced ethanol production from brewer's spent grain by a Fusarium oxysporum consolidated system. Biotechnol. Biofuel. 2, 1-12 (2009). https://doi.org/10. 1186/1754-6834-2-4

92. B. Gunes, J. Stokes, P. Davis, C. Connolly, J. Lawler, Pre-treatments to enhance biogas yield and quality from anaerobic digestion of whiskey distillery and brewery wastes: A review. Renew. Sust. Energ. Rev. 113, 109281 (2009). https://doi.org/10.1016/j. rser.2019.109281

93. A. Szaja, A. Montusiewicz, M. Lebiocka, M. Bis, The effect of brewery spent grain application on biogas yields and kinetics in co-digestion with sewage sludge. PeerJ 8, e10590 (2020). https:// doi.org/10.7717/peerj. 10590

94. M. Panjičko, G.D. Zupančič, L. Fanedl, R.M. Logar, M. Tišma, B. Zelić, Biogas production from brewery spent grain as a monosubstrate in a two-stage process composed of solid-state anaerobic digestion and granular biomass reactors. J. Clean. Prod. 166, 519-529 (2017). https://doi.org/10.1016/j.jclepro.2017.07.197

95. M. Dudek, K. Świechowski, P. Manczarski, J.A. Koziel, A. Białowiec, The effect of biochar addition on the biogas production kinetics from the anaerobic digestion of brewers' spent grain. Energies 12, 1518 (2019). https://doi.org/10.3390/en120 81518

96. S.T. Cooray, J.J.L. Lee, W.N. Chen, Evaluation of brewers' spent grain as a novel media for yeast growth. AMB Express 7(1), 117 (2017). https://doi.org/10.1186/s13568-017-0414-1
97. S.I. Mussatto, M. Fernandes, G. Dragone, I.M. Mancilha, I.C. Roberto, Brewer's spent grain as raw material for lactic acid production by Lactobacillus delbrueckii. Biotechnol. Lett. 29, 1973-1976 (2007). https://doi.org/10.1007/s10529-007-9494-3

98. S. Shindo, T. Tachibana, Production of L-lactic acid from spent grain, a by-product of beer production. J. I. Brewing 110, 347351 (2004). https://doi.org/10.1002/j.2050-0416.2004.tb00631.x

99. J. Pejin, M. Radosavljević, S. Kocić-Tanackov, R. Marković, A. Djukić-Vuković, L. Mojović, Use of spent brewer's yeast in L-(+) lactic acid fermentation. J. I. Brewing 125, 357-363 (2019). https://doi.org/10.1002/jib.572

100. R. Singh, G. Saini, Biosynthesis of pullulan and its applications, in food and pharmaceutical industry, in Microorganisms in sustainable agriculture and biotechnology. ed. by T. Satyanarayana, B. Johri, A. Prakash (Springer, Dordrecht, The Netherlands, 2012), pp. 509-553

101. F. Carvalheiro, L.C. Duarte, R. Medeiros, F.M. Gírio, Xylitol production by Debaryomyces hansenii in brewery spent grain diluteacid hydrolysate: effect of supplementation. Biotechnol. Lett. 29, 1887-1891 (2007). https://doi.org/10.1007/ s10529-007-9468-5

102. F. Carvalheiro, L.C. Duarte, S. Lopes, J.C. Parajò, H. Pereira, F.M. Gírio, Supplementation requirements of brewery's spent grain hydrolysate for biomass and xylitol production by Debaryomyces hansenii CCMI 941. J. Ind. Microbiol. Biotechnol. 33, 646-654 (2006). https://doi.org/10.1007/s10295-006-0101-8

103. F. Carvalheiro, L.C. Duarte, S. Lopes, J.C. Parajò, H. Pereira, F.M. Gírio, Evaluation of the detoxification of brewery's spent grain hydrolysate for xylitol production by Debaryomyces hansenii CCMI 941. Process Biochem. 40, 1215-1223 (2005). https:// doi.org/10.1016/j.procbio.2004.04.015

104. T.O. Femi-Ola, V.A. Atere, Citric acid production from brewers spent grain by Aspergillus niger and Saccharomyces cerevisiae. Int. J. Res. BioSci. 2, 30-36 (2013)

105. R. Balakrishnan, S.K. Rajaram, S. Sivaprakasam, Biovalorization potential of agro-forestry/industry biomass for optically pure lactic acid fermentation: Opportunities and challenges, in Biovalorisation of Wastes to Renewable Chemicals and Biofuels. ed. by N.K. Rathinam, R.K. Sani (Elsevier, Cambridge, MA, USA, 2020), pp. 261-276

106. S. Inkinen, M. Hakkarainen, A.C. Albertsson, A. Södergård, From Lactic Acid to Poly(lactic acid) (PLA): Characterization and Analysis of PLA and Its Precursors. Biomacromol 12(3), 523-532 (2011). https://doi.org/10.1021/bm101302t

107. Z. Liu, Y. Wang, B. Wu, C. Cui, Y. Guo, C. Yan, A critical review of fused deposition modeling 3D printing technology in manufacturing polylactic acid parts. Int. J. Adv. Manuf. Technol. 102, 2877-2889 (2019). https://doi.org/10.1007/s00170-019-03332-x

108. B. Choi, S. Yoo, S. Park, Carbon footprint of packaging films made from LDPE, PLA, and PLA/PBAT blends in South Korea. Sustainability 10, 2369 (2018). https://doi.org/10.3390/su100 72369

109. S.T. Cooray, W.N. Chen, Valorization of brewer's spent grain using fungi solid-state fermentation to enhance nutritional value. J. Funct. Food. 42, 85-94 (2018). https://doi.org/10.1016/j.jff. 2017.12.027

110. S. Liang, C. Wan, Carboxylic acid production from brewer's spent grain via mixed culture fermentation. Bioresource Technol. 182, 179-183 (2015). https://doi.org/10.1016/j.biortech.2015.01. 082

111. J. Yang, A.R. Webb, G.A. Ameer, Novel Citric Acid-Based Biodegradable Elastomers for Tissue Engineering. Adv. Mater. 16, 511-516 (2004). https://doi.org/10.1002/adma.200306264

112. H. Namazi, M. Adeli, Dendrimers of citric acid and poly (ethylene glycol) as the new drug-delivery agents. Biomaterials 26,

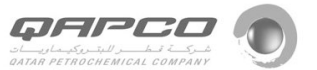


1175-1183 (2005). https://doi.org/10.1016/j.biomaterials.2004. 04.014

113. I. Djordjevic, N.R. Choudhury, N.K. Dutta, S. Kumar, Synthesis and characterization of novel citric acid-based polyester elastomers. Polymer 50, 1682-1691 (2009). https://doi.org/10.1016/j. polymer.2009.01.045

114. D. Gyawali, P. Nair, Y. Zhang, R.T. Tran, C. Zhang, M. Samchukov, M. Makarov, H.K.W. Kim, J. Yang, Citric acid-derived in situ crosslinkable biodegradable polymers for cell delivery. Biomaterials 31, 9092-9105 (2010). https://doi.org/10.1016/j. biomaterials.2010.08.022

115. C. Demitri, R. Del Sole, F. Scalera, A. Sannino, G. Vasapollo, A. Maffezzoli, L. Ambrosio, L. Nicolais, Novel superabsorbent cellulose-based hydrogels crosslinked with citric acid. J. Appl. Polym. Sci. 110, 2453-2460 (2008). https://doi.org/10.1002/app. 28660

116. N. Reddy, Y. Yang, Citric acid cross-linking of starch films. Food Chem. 118, 702-711 (2010). https://doi.org/10.1016/j.foodchem. 2009.05.050

117. W. Woigk, C.A. Fuentes, J. Rion, D. Hegemann, A.W. van Vuure, E. Kramer, C. Dransfeld, K. Masania, Fabrication of flax fibrereinforced cellulose propionate thermoplastic composites. Compos. Sci. Technol. 183, 107791 (2019). https://doi.org/10.1016/j. compscitech.2019.107791

118. H. Shaghaleh, X. Xu, S. Wang, Current progress in production of biopolymeric materials based on cellulose, cellulose nanofibers, and cellulose derivatives. RSC Adv. 8(2), 825-842 (2018). https://doi.org/10.1039/c7ra11157f

119. F. Sharif, N. Muhammad, T. Zafar, Cellulose Based Biomaterials: Benefits and Challenges, in Biofibers and Biopolymers for Biocomposites, ed. By A. Khan, S. Mavinkere Rangappa, S. Siengchin, A. Asiri (Springer, Dordrecht, The Netherlands, 2020). https://doi.org/10.1007/978-3-030-40301-0_11

120. C. Gauss, K.L. Pickering, L.P. Muthe, The use of cellulose in bio-derived formulations for 3D/4D printing: A review. Compos. Part C-Open Access 4, 100113 (2021). https://doi.org/10.1016/j. jcomc.2021.100113

121. P. Puligundla, C. Mok, Recent advances in biotechnological valorization of brewers' spent grain. Food Sci. Biotechnol. 30, 341-353 (2021). https://doi.org/10.1007/s10068-021-00900-4

122. D.S. Tang, Y.J. Tian, Y.Z. He, L. Li, S.Q. Hu, B. Li, Optimisation of ultrasonic-assisted protein extraction from brewer's spent grain. Czech J. Food Sci. 28, 9-17 (2010)

123. D.S. Tang, G.M. Yin, Y.Z. He, S.Q. Hu, B. Li, L. Li, H.L. Liang, D. Borthakur, Recovery of protein from brewer's spent grain by ultrafiltration. Biochem. Eng. J. 48(1), 1-5 (2009). https://doi. org/10.1016/j.bej.2009.05.019

124. Q. Yanlin, Research Advance and Propect of Comprehensive Use of Brewer's Spent Grain by Biotechnology. Food Ferment. Ind. 28(1), 72-73 (2002)

125. G. Pierre, F. Sannier, R. Goude, A. Nouviaire, Z. Maache-Rezzoug, S.A. Rezzoug, T. Maugard, Evaluation of thermomechanical pretreatment for enzymatic hydrolysis of pure microcrystalline cellulose and cellulose from Brewers' spent grain. J. Cereal Sci. 54(3), 305-310 (2011). https://doi.org/10.1016/j.jcs.2011. 06.004

126. P.K. Mishra, T. Gregor, R. Wimmer, Utilising Brewer's Spent Grain as a Source of Cellulose Nanofibres Following Separation of Protein-based Biomass. Bio Resources. 12(1), 107-116 (2016). https://doi.org/10.15376/biores.12.1.107-116

127. R.D. Chen, C.F. Huang, S. Hsu, Composites of waterborne polyurethane and cellulose nanofibers for 3D printing and bioapplications. Carbohyd. Polym. 212, 75-88 (2019). https://doi.org/10. 1016/j.carbpol.2019.02.025

128. M. Li, X. Tian, R. Jin, D. Li, Preparation and characterization of nanocomposite films containing starch and cellulose nanofibers.
Ind. Crop. Prod. 123, 654-660 (2018). https://doi.org/10.1016/j. indcrop.2018.07.043

129. A. Ghanbari, T. Tabarsa, A. Ashori, A. Shakeri, M. Mashkour, Thermoplastic starch foamed composites reinforced with cellulose nanofibers: Thermal and mechanical properties. Carbohyd. Polym. 197, 305-311 (2018). https://doi.org/10.1016/j.carbpol. 2018.06.017

130 D.M. Santos, A.L. de Bukzem, D.P.R. Ascheri, R. Signini, G.L.B. de Aquino, Microwave-assisted carboxymethylation of cellulose extracted from brewer's spent grain. Carbohyd. Polym. 131, 125-133 (2015). https://doi.org/10.1016/j.carbpol.2015.05. 051

131. S.I. Mussatto, M. Fernandes, I.C. Roberto, Lignin recovery from brewer's spent grain black liquor. Carbohyd. Polym. 70(2), 218223 (2007). https://doi.org/10.1016/j.carbpol.2007.03.021

132. S.I. Mussatto, I.C. Roberto, Chemical characterization and liberation of pentose sugars from brewer's spent grain. J. Chem. Technol. Biotechnol. 81, 268-274 (2006). https://doi.org/10. $1002 /$ jctb. 1374

133. M. Mendis, S. Simsek, Arabinoxylans and human health. Food Hydrocolloid. 42, 239-243 (2014). https://doi.org/10.1016/j. foodhyd.2013.07.022

134. R.S. Rao, G. Muralikrishna, Water soluble feruloyl arabinoxylans from rice and ragi: changes upon malting and their consequence on antioxidant activity. Phytochem 67(1), 91-99 (2006). https:// doi.org/10.1016/j.phytochem.2005.09.036

135 C. Péroval, F. Debeaufort, D. Despré, A. Voilley, Edible Arabinoxylan-Based Films. 1. Effects of Lipid Type on Water Vapor Permeability, Film Structure, and Other Physical Characteristics. J. Agr. Food Chem. 50(14), 3977-3983 (2002). https://doi.org/ $10.1021 / \mathrm{jf0} 116449$

136. A. Höije, M. Gröndahl, K. Tømmeraas, P. Gatenholm, Isolation and characterization of physicochemical and material properties of arabinoxylans from barley husks. Carbohyd. Polym. 61(3), 266-275 (2005). https://doi.org/10.1016/j.carbpol.2005.02.009

137. A. Höije, E. Sternemalm, S. Heikkinen, M. Tenkanen, P. Gatenholm, Material Properties of Films from Enzymatically Tailored Arabinoxylans. Biomacromol 9(7), 2042-2047 (2008). https:// doi.org/10.1021/bm800290m

138. Y. Zhang, L. Pitkänen, J. Douglade, M. Tenkanen, C. Remond, C. Joly, Wheat bran arabinoxylans: Chemical structure and film properties of three isolated fractions. Carbohyd. Polym. 86(2), 852-859 (2011). https://doi.org/10.1016/j.carbpol.2011.05.036

139. J.S. Stevanic, E.M. Bergström, P. Gatenholm, L. Berglund, L. Salmen, Arabinoxylan/nanofibrillated cellulose composite films. J. Mater. Sci. 47, 6724-6732 (2012). https://doi.org/10.1007/ s10853-012-6615-8

140. G. Mandalari, C.B. Faulds, A.I. Sancho, A. Saija, G. Bisignano, R. LoCurto, K.W. Waldron, Fractionation and characterisation of arabinoxylans from brewers' spent grain and wheat bran. J. Cereal Sci. 42(2), 205-212 (2005). https://doi.org/10.1016/j.jcs. 2005.03.001

141. E. Coelho, M.A.M. Rocha, A.S.P. Moreira, M.R.M. Domingues, M.A. Coimbra, Revisiting the structural features of arabinoxylans from brewers' spent grain. Carbohyd. Polym. 139, 167-176 (2016). https://doi.org/10.1016/j.carbpol.2015.12.006

142. E. Vieira, M.A.M. Rocha, E. Coelho, O. Pinho, J.A. Saraiva, I.M.P.L.V.O. Ferreira, M.A. Coimbra, Valuation of brewer's spent grain using a fully recyclable integrated process for extraction of proteins and arabinoxylans. Ind. Crop. Prod. 52, 136-143 (2014). https://doi.org/10.1016/j.indcrop.2013.10.012

143. S.F. Reis, E. Coelho, M.A. Coimbra, N. Abu-Ghannam, Influence of grain particle sizes on the structure of arabinoxylans from brewer's spent grain. Carbohyd. Polym. 130, 222-226 (2015). https://doi.org/10.1016/j.carbpol.2015.05.031 
144. C. Moreirinha, C. Vilela, N.H.C.S. Silva, R.R.J. Pinto, A. Almeida, M.A.M. Rocha, E. Coelho, M.A. Coimbra, A.J.D. Silvestre, C.S.R. Freire, Antioxidant and antimicrobial films based on brewers spent grain arabinoxylans, nanocellulose and feruloylated compounds for active packaging. Food Hydrocolloid. 108, 105836 (2020). https://doi.org/10.1016/j.foodhyd.2020. 105836

145. C. Xiros, M. Moukouli, E. Topakas, P. Christakopoulos, Factors affecting ferulic acid release from Brewer's spent grain by Fusarium oxysporum enzymatic system. Bioresource Technol. 100, 5917-5921 (2009). https://doi.org/10.1016/j.biortech.2009. 06.018

146. M.M. Moreira, S. Morais, A.A. Barros, C. Delerue-Matos, L.F. Guido, A novel application of microwave-assisted extraction of polyphenols from brewer's spent grain with HPLC-DAD-MS analysis. Anal. Bioanal. Chem. 403, 1019-1029 (2012). https:// doi.org/10.1007/s00216-011-5703-y

147. C.B. Faulds, G. Mandalari, R. Locurto, G. Bisignano, K.W. Waldron, Arabinoxylan and mono- and dimeric ferulic acid release from brewers' grain and wheat bran by feruloyl esterases and glycosyl hydrolases from Humicola insolens. Appl. Microbiol. Biot. 64, 644-650 (2004). https://doi.org/10.1007/s00253-003-1520-3

148. K. Moraczewski, A. Pawłowska, M. Stepczyńska, R. Malinowski, D. Kaczor, B. Budner, K. Gocman, P. Rytlewski, Plant extracts as natural additives for environmentally friendly polylactide films. Food Pack. Shelf Life 26, 100593 (2020). https://doi.org/10. 1016/j.fpsl.2020.100593

149. J. Liszkowska, M. Borowicz, J. Paciorek-Sadowska, M. Isbrandt, B. Czupryński, K. Moraczewski, Assessment of photodegradation and biodegradation of RPU/PIR foams modified by natural compounds of plant origin. Polymers 12, 33 (2020). https://doi. org/10.3390/polym12010033

150. K. Moraczewski, R. Malinowski, W. Sikorska, T. Karasiewicz, M. Stepczyńska, B. Jagodziński, P. Rytlewski, Composting of polylactide containing natural anti-aging compounds of plant origin. Polymers 11, 1582 (2019). https://doi.org/10.3390/polym 11101582

151 X.J. Wang, J.C. Qi, X. Wang, L.P. Cao, Extraction of polyphenols from barley (Hordeum vulgare L.) grain using ultrasoundassisted extraction technology. Asia. J. Chem. 25(3), 1324-1330 (2013)

152. S. Spinelli, A. Conte, L. Lecce, L. Padalino, M.A. Del Nobile, Supercritical carbon dioxide extraction of brewer's spent grain. J. Supercrit. Fluid. 107, 69-74 (2016). https://doi.org/10.1016/j. supflu.2015.08.017

153. W. Routray, V. Orsat, Microwave-assisted extraction of flavonoids: a review. Food Bioprocess Technol. 5(2), 409-424 (2012). https://doi.org/10.1007/s11947-011-0573-z

154. J. Steiner, S. Procopio, T. Becker, Brewer's spent grain: Source of value-added polysaccharides for the food industry in reference to the health claims. Eur. Food Res. Technol. 241(3), 303-315 (2015). https://doi.org/10.1007/s00217-015-2461-7

155. F.K. Nzekoue, S. Angeloni, L. Navarini, C. Angeloni, M. Freschi, S. Hrelia, L.A. Vitali, G. Sagratini, S. Vittori, G. Caprioli, Coffee silverskin extracts: Quantification of 30 bioactive compounds by a new HPLC-MS/MS method and evaluation of their antioxidant and antibacterial activities. Food Res. Int. 133, 109128 (2020). https://doi.org/10.1016/j.foodres.2020.109128

156. A. Guglielmetti, V. D'Ignoti, D. Ghirardello, S. Belviso, G. Zeppa, Optimisation of ultrasound and microwave-assisted extraction of caffeoylquinic acids and caffeine from coffee silverskin using response surface methodology. Italian J. Food Sci. 29(3), 409-423 (2017). https://doi.org/10.14674/IJFS-727

157. A. Hejna, Potential applications of by-products from the coffee industry in polymer technology - Current state and perspectives.
Waste Manage. 121, 296-330 (2021). https://doi.org/10.1016/j. wasman.2020.12.018

158. T. Bonifácio-Lopes, J.A. Teixeira, M. Pintado, Current extraction techniques towards bioactive compounds from brewer's spent grain - A review. Crit. Rev. Food Sci. Nutr. 60, 2730-2741 (2020). https://doi.org/10.1080/10408398.2019.1655632

159. A. Hejna, P. Kosmela, M. Kopczynska, J. Haponiuk, L. Piszczyk, Microwave Assisted Liquefaction with Crude Glycerol as a Potential Method of Brewer's Spent Grain Utilization. Chem. Chem. Technol. 10(4), 445-450 (2016). https://doi.org/10.23939/ chcht10.04.445

160. L. Krišták, R. Réh, Application of Wood Composites. Appl. Sci. 11, 3479 (2021). https://doi.org/10.3390/app11083479

161. S.T. Cholake, R. Rajarao, P. Henderson, R.R. Rajagopal, V. Sahajwalla, Composite panels obtained from automotive waste plastics and agricultural macadamia shell waste. J. Clean. Prod. 151, 163-171 (2017). https://doi.org/10.1016/j.jclepro.2017.03. 074

162. K.S. Chun, V. Subramaniam, C.M. Yeng, P.M. Meng, C.T. Ratnam, T.K. Yeow, C.K. How, Wood plastic composites made from post-used polystyrene foam and agricultural waste. J. Thermoplast. Compos. Mater. 32, 1455-1466 (2019). https:// doi.org/10.1177/0892705718799836

163. A. Hejna, K. Formela, M.R. Saeb, Processing, mechanical and thermal behavior assessments of polycaprolactone/agricultural wastes biocomposites. Ind. Crop. Prod. 76, 725-733 (2015). https://doi.org/10.1016/j.indcrop.2015.07.049

164. A. Revert, M. Reig, V.J. Seguí, T. Boronat, V. Fombuena, R. Balart, Upgrading brewer's spent grain as functional filler in polypropylene matrix. Polym. Compos. 38(1), 40-47 (2015). https://doi.org/10.1002/pc.23558

165. M.C. Barbu, Z. Montecuccoli, J. Förg, U. Barbeck, P. Klímek, A. Petutschnigg, E.M. Tudor, Potential of Brewer's Spent Grain as a Potential Replacement of Wood in pMDI. UF or MUF Bonded Particleboard. Polymers 13, 319 (2021). https:// doi.org/10.3390/polym13030319

166. P. Antov, L. Krišták, R. Réh, V. Savov, A.N. Papadopoulos, Eco-Friendly Fiberboard Panels from Recycled Fibers Bonded with Calcium Lignosulfonate. Polymers 13, 639 (2021). https:// doi.org/10.3390/polym13040639

167. P. Antov, G.I. Mantanis, V. Savov, Development of wood composites from recycled fibres bonded with magnesium lignosulfonate. Forests 11(6), 613 (2020). https://doi.org/10.3390/ f11060613

168. R. Réh, L. Krištak, J. Sedliačik, P. Bekhta, M. Božiková, D. Kunecová, V. Vozárová, E.M. Tudor, P. Antov, V. Savov, Utilization of birch bark as an eco-friendly filler in urea-formaldehyde adhesives for plywood manufacturing. Polymers 13, 511 (2021). https://doi.org/10.3390/polym13040511

169. P. Klímek, R. Wimmer, P Kumar Mishra, J Kúdela, Utilizing brewer's-spent-grain in wood-based particleboard manufacturing. J. Clean. Prod. 141, 812-817 (2017). https://doi.org/10. 1016/j.jclepro.2016.09.152

170. A.M. Ferreira, J. Martins, L.H. Carvalho, F.D. Magalhães, Biosourced disposable trays made of brewer's spent grain and potato starch. Polymers 11, 923 (2019). https://doi.org/10. 3390/polym 11050923

171 A. Hejna, J. Haponiuk, Ł Piszczyk, M. Klein, K. Formela, Performance properties of rigid polyurethane-polyisocyanurate/ brewers' spent grain foamed composites as function of isocyanate index. e-Polymers. 17(5), 427-437 (2017). https://doi. org/10.1515/epoly-2017-0012

172. K. Formela, A. Hejna, Ł Zedler, M. Przybysz, J. Ryl, M.R. Saeb, Ł Piszczyk, Structural, thermal and physico-mechanical properties of polyurethane/brewers' spent grain composite 
foams modified with ground tire rubber. Ind. Crop. Prod. 108, 844-852 (2017). https://doi.org/10.1016/j.indcrop.2017.07.047

173. A. Hejna, M. Barczewski, K. Skórczewska, J. Szulc, B. Chmielnicki, J. Korol, K. Formela, Sustainable upcycling of brewers' spent grain by thermo-mechanical treatment in twinscrew extruder. J. Clean. Prod. 285, 124839 (2021). https://doi. org/10.1016/j.jclepro.2020.124839

174. A. Hejna, M. Barczewski, P. Kosmela, O. Mysiukiewicz, Inhibition of Polymer Photodegradation by Incorporation of Coffee Silverskin. Proceedings. 69, 1 (2021). https://doi.org/10.3390/ CGPM2020-07219

175. A. Hejna, Poly( $\varepsilon$-Caprolactone)/Brewers' Spent Grain Composites-The Impact of Filler Treatment on the Mechanical Performance. J. Compos. Sci. 4, 167 (2020). https://doi.org/ $10.3390 /$ jcs 4040167

176. A. Hejna, J. Korol, P. Kosmela, A. Kuzmin, A. Piasecki, A. Kulawik, B. Chmielnicki, By-products from food industry as a promising alternative for the conventional fillers for woodpolymer composites. Polymers 13, 893 (2021). https://doi.org/ 10.3390/polym 13060893

177. S. Lu, S.W. Gibb, Copper removal from wastewater using spentgrain as biosorbent. Bioresource Technol. 99, 1509-1517 (2008). https://doi.org/10.1016/j.biortech.2007.04.024

178. K.S. Low, C.K. Lee, C.H. Low, Sorption of chromium (VI) by spent grain under batch conditions. J. Appl. Polym. Sci. 82, 2128-2134 (2001). https://doi.org/10.1002/app.2058

179. Q. Li, L. Chai, Z. Yang, Q. Wang, Kinetics and thermodynamics of $\mathrm{Pb}(\mathrm{II})$ adsorption onto modified spent grain from aqueous solutions. Appl. Surface Sci. 255, 4298-4303 (2009). https://doi.org/10.1016/j.apsusc.2008.11.024

180. N. Ishiwaki, H. Murayama, H. Awayama, O. Kanauchi, T. Sato, Development of high value uses of spent grain by fractionation technology. MBAA Tech. Quarter. 37, 261-265 (2000)

181. A.I. Osman, E. O'Connor, G. McSpadden, J.K. Abu-Dahrieh, C. Farrell, A.H. Al-Muhtaseb, J. Harrison, D.W. Rooney, Upcycling brewer's spent grain waste into activated carbon and carbon nanotubes via two-stage activation for energy and other applications. J. Chem. Technol. Biotechnol. 95(1), 183-195 (2020). https://doi.org/10.1002/jctb.6220

182. J.P. Silva, S. Sousa, I. Goncalves, J.J. Porter, S. Ferreira-Dias, Modeling adsorption of acid orange 7 dye in aqueous solutions to spent brewery grains. Sep. Purif. Technol. 40, 163-170 (2004). https://doi.org/10.1016/j.seppur.2004.02.006

183. P. Silva, S. Sousa, J. Rodrigues, H. Antunes, J.J. Porter, I. Goncalves, S. Ferreira-Dias, Adsorption of acid orange 7 dye in aqueous solutions by spent brewery grains. Sep. Purif. Technol. 40, 309-315 (2004). https://doi.org/10.1016/j.seppur.2004. 03.010

184. A. Kezerle, N. Velic, D. Hasenay, D. Kovacevic, Lignocellulosic Materials as Dye Adsorbents: Adsorption of Methylene Blue and Congo Red on Brewers' Spent Grain. Croatica Chem. Acta 91(1), 53-64 (2018). https://doi.org/10.5562/cca3289

185. J. Wu, Z. Zhang, J. Xu, X. Lu, C. Wang, H. Xu, H. Yuan, J. Zhang, Brewer's grains with different pretreatments used as bio-adsorbents for the removal of Congo red dye from aqueous solution. BioResources 15(3), 6928-6940 (2020)

186. P.C. Chiang, P. Chang, J.H. You, Innovative technology for controlling VOC emissions. J. Hazard. Mater. 31, 19-28 (1992). https://doi.org/10.1016/0304-3894(92)87036-F

187. Q. Li, L. Chai, W. Qin, Cadmium(II) adsorption on esterified spent grain: equilibrium modeling and possible mechanisms. Chem. Eng. J. 197, 173-180 (2012). https://doi.org/10.1016/j. cej.2012.04.102

188. K.S. Low, C.K. Lee, S.C. Liew, Sorption of cadmium and lead from aqueous solutions by spent grain. Process Biochem. 36, 59-64 (2000). https://doi.org/10.1016/S0032-9592(00)00177-1
189. O.C. Izinyon, O.E. Nwosu, L.O. Akhigbe, I.R. Ilaboya, Performance evaluation of $\mathrm{Fe}$ (III) adsorption onto brewers' spent grain. Niger. J. Technol. 35, 970-978 (2016). https://doi.org/ 10.4314/njt.v35i4.36

190. L. Chai, Q. Li, Y. Zhu, Z. Zhang, Q. Wang, Y. Wang, Z. Yang, Synthesis of thiol-functionalized spent grain as a novel adsorbent for divalent metal ions. Bioresource Technol. 101(15), 6269-6272 (2010). https://doi.org/10.1016/j.biortech.2010.03. 009

191. D. Kukić, M. Šćiban, J. Pejin, V. Vasić, J. Prodanović, Brewer's spent grain as a potential adsorbent of heavy metal ions from water. Zaštita materijala 57(3), 397-403 (2016)

192. T.R.S. Mathias, P.P. Moretzsohn de Mello, E.F.C. Servulo, Solid wastes in brewing process: A review. J. Brewing Distill. 5(1), 1-9 (2014). https://doi.org/10.5897/JBD2014.0043

193. B. Jaskula, E. Syryn, K. Goiris, G. De Rouck, F. Van Opstaele, J. De Clippeleer, G. Aerts, L. De Cooman, Hopping technology in relation to beer bitterness consistency and flavor stability. J. Am. Soc. Brew. Chem. 65(1), 38-46 (2007). https://doi.org/10. 1094/asbcj-2007-0112-03

194. T. Amoriello, R. Ciccoritti, Sustainability: recovery and reuse of brewing-derived by-products. Sustainability 13, 2355 (2021). https://doi.org/10.3390/su13042355

195. S.I. Mussatto, Biotechnological potential of brewing industry by-products, in biotechnology for agro-industrial residues utilisation, ed. By P. Singh nee' Nigam, A. Pandey (Springer, Dordrecht, The Netherlands, 2009), pp. 313-326. https://doi.org/ 10.1007/978-1-4020-9942-7_16

196. H.M. Esslinger, L. Narziss, Beer (Wiley-VCH Verlag GmbH \& Co. KGaA, Weinheim, Germany, 2005)

197 S. Bedini, G. Flamini, J. Girardi, F. Cosci, B. Conti, Not just for beer: evaluation of spent hops (Humulus lupulus L.) as a source of eco-friendly repellents for insect pests of stored foods. J. Pest Sci. 88(3), 583-592 (2015). https://doi.org/10.1007/ s10340-015-0647-1

198. T. O'Rourke, Making the most of your hops. New Brewer 11, 20-33 (1994)

199. W. RuB, R. Meyer-Pittroff, The use of phenolic protein precipitates (trub) from beer production in animal feed. Monatsschr Brauwiss 56, 84-88 (2003)

200. E. Huszcza, A. Bartmanska, The implication of yeast in debittering of spent hops. Enzyme Microb. Technol. 42, 421-425 (2008). https://doi.org/10.1016/j.enzmictec.2008.01.004

201. E. Huszcza, A. Bartmanska, M. Anioł, W. Mączka, A. Żołnierczyk, C. Wawrzeńczyk, Degradation of hop bitter acids by fungi. Waste Manage. 28, 1406-1410 (2008). https://doi.org/ 10.1016/j.wasman.2007.06.014

202. B.R. Saraiva, F.A. Anjo, A.C.P. Vital, L.H.M. da Silva, C.Y.L. Ogawa, F. Sato, L.B. Coimbra, P.T. Matumoto-Pintro, Waste from brewing (trub) as a source of protein for the food industry. Int. J. Food Sci. Technol. 54(4), 1247-1255 (2019). https://doi. org/10.1111/ijfs.14101

203. E.K. Nassary, E.R. Nasolwa, Unravelling disposal benefits derived from underutilized brewing spent products in Tanzania. J. Environ. Manage. 242, 430-439 (2019). https://doi.org/10. 1016/j.jenvman.2019.04.068

204 J. Mediouni-Ben-Jemaa, N. Tersim, K. Talebtoudert, M.L. Khouja, Insecticidal activities of oils from leaves of Laurus nobilis L. from Tunisia, Algeria and Morocco, and comparative chemical composition. J. Stored Prod. Res. 48, 97-104 (2012). https://doi.org/10.1016/j.jspr.2011.10.003

205. G. Benelli, G. Flamini, A. Canale, P.L. Cioni, I. Molfetta, B. Conti, Repellence of Hyptis suaveolens whole essential oil and major constituents against adults of the granary weevil Sitophilus granarius. Bull. Insectol. 65, 177-183 (2012) 
206. A. Bartmańska, E. Wałecka-Zacharska, T. Tronina, J. Popłoński, S. Sordon, E. Brzezowska, J. Bania, E. Huszcza, Antimicrobial properties of spent hops extracts, flavonoids isolated therefrom, and their derivatives. Molecules 23, 2059 (2018). https://doi.org/ 10.3390/molecules23082059

207. M. Anioł, E. Huszcza, A. Bartmanska, A. Zołnierczyk, W. Maczka, C. Wawrzenczyk, Trace analysis of hop essential oils in spent hop. J. Am. Soc. Brew. Chem. 65, 214-218 (2007). https:// doi.org/10.1094/ASBCJ-2007-0820-01

208. G. Laufenberg, B. Kunz, M. Nystroem, Transformation of vegetable waste into value added products: (A) the upgrading concept; (B) practical implementation. Bioresource Technol. 87, 167-198 (2003). https://doi.org/10.1016/S0960-8524(02)00167-0

209. K. Fischer, H.P. Bipp, Generation of organic acids and monosaccharides by hydrolytic and oxidative transformation of food processing residues. Bioresource Technol. 96, 831-842 (2005). https://doi.org/10.1016/j.biortech.2004.07.003

210. A. Grudniewska, J. Popłoński, Simple and green method for the extraction of xanthohumol from spent hops using deep eutectic solvents. Sep. Purif. Technol. 250, 117196 (2020). https://doi. org/10.1016/j.seppur.2020.117196

211. F. Kuhbeck, M. Muller, W. Back, T. Kurz, M. Krottenthaler, Effect of hot trub and particle addition on fermentation performance of Saccharomyces cerevisiae. Enzyme Microb. Technol. 41, 711-720 (2007). https://doi.org/10.1016/j.enzmictec.2007. 06.007

212. R.B. Gilliland, Yeast reproduction during fermentation. J. I. Brewing 68(3), 271-275 (1962). https://doi.org/10.1002/j. 2050-0416.1962.tb01863.x

213. M.J. Lewis, T.W. Young, Brewing (Chapman and Hall, London, UK, 1995)

214. C. Kerby, F. Vriesekoop, An overview of the utilisation of brewery by-products as generated by british craft breweries. Beverages 3, 24 (2017). https://doi.org/10.3390/beverages3 020024

215. J. Liepins, E. Kovačova, K. Shvirksts, M. Grube, A. Rapoport, G. Kogan, Drying enhances immunoactivity of spent brewer's yeast cell wall $\beta$-d-glucans. J. Biotechnol. 206, 12-16 (2015). https:// doi.org/10.1016/j.jbiotec.2015.03.024

216. B. Podpora, F. Świderski, A. Sadowska, R. Rakowska, G. Wasiak-Zys, Spent brewer's yeast extracts as a new component of functional food. Czech J. Food Sci. 34(6), 554-563 (2016). https://doi.org/10.17221/419/2015-CJFS

217. F.F. Jacob, M. Hutzler, F.J. Methner, Comparison of various industrially applicable disruption methods to produce yeast extract using spent yeast from top-fermenting beer production: Influence on amino acid and protein content. Eur. Food Res. Technol. 245, 95-109 (2019). https://doi.org/10.1007/ s00217-018-3143-z

218. E.F. Vieira, J. Carvalho, E. Pinto, S. Cunha, A.A. Almeida, I.M. Ferreira, Nutritive value, antioxidant activity and phenolic compounds profile of brewer's spent yeast extract. J. Food Compos. Anal. 52, 44-51 (2016). https://doi.org/10.1016/j.jfca.2016.07. 006

219. A. Jaeger, E.K. Arendt, E. Zannini, A.W. Sahin, Brewer's Spent Yeast (BSY), an Underutilized Brewing By-Product. Fermentation 6, 123 (2020). https://doi.org/10.3390/fermentation6040123

220. L. Kruger, A.T.W. Pickerell, B. Axcell, The sensitivity of different brewing yeast strains to carbon dioxide inhibition: Fermentation and production of flavour-active volatile compounds. J. I. Brewing 98(2), 133-138 (1992). https://doi.org/10.1002/j. 2050-0416.1992.tb01100.x

221. M. Boateng, D.B. Okai, Y.O. Frimpong, Y.Y. Zeebone, Wet brewers' spent grains and wet brewers' spent yeast: problems associated with their usage and suggested solutions: A case study of the Ejisu-Juaben Municipality of Ghana. Livest. Res. Rural Develop. 27, 5 (2015)

222. J. Wohlt, T. Corcione, P. Zajac, Effect of yeast on feed intake and performance of cows fed diets based on corn silage during early lactation. J. Dairy Sci. 81, 1345-1352 (1998). https://doi.org/10. 3168/jds.S0022-0302(98)75697-8

223. A. Vohra, P. Syal, A. Madan, Probiotic yeasts in livestock sector. Anim. Feed Sci. Technol. 219, 31-47 (2016). https://doi.org/10. 1016/j.anifeedsci.2016.05.019

224. B. Harlow, R. Bryant, S. Cohen, S. O'Connell, M.D. Flythe, Degradation of spent craft brewer's yeast by caprine rumen hyper ammonia-producing bacteria. Lett. Appl. Microbiol. 63, 307-312 (2016). https://doi.org/10.1111/lam.12623

225. C.A. Nugent, F.H. Tyler, The renal excretion of uric acid in patients with gout and in nongouty subjects. J. Clin. Inv. 38(11), 1890-1898 (1959). https://doi.org/10.1172/JCI103966

226. R. Rakowska, A. Sadowska, E. Dybkowska, F. Świderski, Spent yeast as natural source of functional food additives. Rocz. Panstw. Zakl. Hig. 68(2), 115-121 (2017)

227 G.V. Marson, R.J.S. de Castro, M.P. Belleville, M. DupasHubinger, Spent brewer's yeast as a source of high added value molecules: a systematic review on its characteristics, processing and potential applications. World J. Microbiol. Biotechnol. 36, 95 (2020). https://doi.org/10.1007/s11274-020-02866-7

228. P. Puligundla, C. Mok, S. Park, Advances in the valorization of spent brewer's yeast. Innov. Food Sci. Emerg. 62, 102350 (2020). https://doi.org/10.1016/j.ifset.2020.102350

229. U. Ben-Hamed, H. Seddighi, K. Thomas, Economic Returns of Using Brewery`s Spent Grain in Animal Feed. Int. J. Econ. Manage. Eng. 5(2), 142-145 (2011)

230. V. Pszczolkowski, R. Bryant, B. Harlow, G. Aiken, L. Martin, M. Flythe, Effects of spent craft brewers' yeast on fermentation and methane production by rumen microorganisms. Adv. Microbiol. 6, 716-723 (2016). https://doi.org/10.4236/aim.2016.69070

231. F.F. Jacob, L. Striegel, M. Rychlik, M. Hutzler, F.J. Methner, Spent yeast from brewing processes: a biodiverse starting material for yeast extract production. Fermentation 5, 51 (2019). https://doi.org/10.3390/fermentation5020051

232. Characteristics and potential applications, I.M.P.L.V.O. Ferreira, O. Pinhoa, E. Vieira, J.G. Tavarelaa, Brewer's Saccharomyces yeast biomass. Trends Food Sci. Technol. 21, 77-84 (2010). https://doi.org/10.1016/j.tifs.2009.10.008

233. E.F. Vieira, O. Pinho, I.M. Ferreira, Bio-functional properties of sardine protein hydrolysates obtained by brewer's spent yeast and commercial proteases. J. Sci. Food Agric. 97, 5414-5422 (2017). https://doi.org/10.1002/jsfa.8432

234. E.F. Vieira, J. Van Camp, I. Ferreira, C. Grootaert, Protein hydrolysate from canned sardine and brewing by-products improves TNF- $\alpha$-induced inflammation in an intestinal-endothelial coculture cell model. Eur. J. Nutr. 57, 2275-2286 (2017). https:// doi.org/10.1007/s00394-017-1503-2

235. T.R.D.S. Mathias, P.F. De Aguiar, J.B.D.A.E. Silva, P.P.M. De Mello, E.F.C. Sérvulo, Brewery Waste Reuse for Protease Production by Lactic Acid Fermentation. Food Technol. Biotechnol. 55, 218-224 92017). https://doi.org/10.17113/ftb.55.02.17.4378

236. D. Djokoto, V. Dzogbefia, J. Oldham, Rapid Extraction of Pawpaw Juice with the Application of Locally Produced Pectic Enzymes from Saccharomyces Cerevisiae ATCC 51712. Food Biotechnol. 20, 31-41 (2006). https://doi.org/10.1080/08905 430500523970

237. V.P. Dzogbefia, E. Amoke, J.H. Oldham, W.O. Ellis, Production and use of yeast pectolytic enzymes to aid pineapple juice extraction. Food Biotechnol. 15, 25-34 (2001). https://doi.org/10.1081/ FBT-100103892

238. J. Kawa-Rygielska, W. Pietrzak, Ethanol fermentation of very high gravity (VHG) maize mashes by Saccharomyces cerevisiae 
with spent brewer's yeast supplementation. Biomass Bioenerg. 60, 50-57 (2014). https://doi.org/10.1016/j.biombioe.2013.10. 028

239. J. Pejin, M. Radosavljević, S. Kocić-Tanackov, R. Marković, A. Djukić-Vuković, L. Mojović, Use of spent brewer's yeast in L-(+) lactic acid fermentation. J. I. Brewing 125(3), 357-363 (2019). https://doi.org/10.1002/jib.572

240. W. Pietrzak, J. Kawa-Rygielska, Utilization of spent brewer's yeast for supplementation of distillery corn mashes. Pol. J. Chem. Technol. 15(4), 102-106 (2013). https://doi.org/10.2478/ pjct-2013-0076

241 R. Spajic, R.T. Burns, L.B. Moody, D. Kralik, V. Poznic, G. Bishop, Croatian food industry by-products: co-digestion with swine manure vs. use as liquid animal feed. T. ASABE 53(4), 1245-1250 (2010). https://doi.org/10.13031/2013

242. J.V. Oliveira, M.M. Alves, J.C. Costa, Biochemical methane potential of brewery by-products. Clean Technol. Envir. 20(2), 435-440 (2018). https://doi.org/10.1007/s10098-017-1482-2

243. G.D.C. Gonçalves, P.K. Nakamura, D.F. Furtado, M.T. Veit, Utilization of brewery residues to produces granular activated carbon and bio-oil. J. Clean. Prod. 168, 908-916 (2017). https:// doi.org/10.1016/j.jclepro.2017.09.089

244. J.G. Zeikus, M.K. Jain, P. Elankovan, Biotechnology of succinic acid production and markets for derived industrial products. Appl. Microbiol. Biotechnol. 51, 545-552 (1999). https://doi. org/10.1007/s002530051431

245. E. Ranucci, Y. Liu, M.S. Lindblad, A.C. Albertsson, New biodegradable polymers from renewable sources. High molecular weight poly(ester carbonate)s from succinic acid and 1,3-propanediol. Macromol Rapid Commun. 21, 680-684 (2000). https:// doi.org/10.1002/1521-3927(20000601)21:10\%3c680::AIDMARC680\%3e3.0.CO;2-Y

246. M. Rakin, M. Vukasinovic, S. Siler-Marinkovic, M. Maksimovic, Contribution of lactic acid fermentation to improved nutritive quality vegetable juices enriched with brewer's yeast autolysate. Food Chem. 100, 599-602 (2007). https://doi.org/10.1016/j. foodchem.2005.09.077

247. C.P. Champagne, H. Gaudreau, J. Conway, Effect of the production or use of mixtures of bakers or brewers' yeast extracts on their ability to promote growth of Lactobacilli and Pediococci. Electron. J. Biotechn. 6, 185-197 (2003)

248. M. Radosavljević, J. Pejin, M. Pribić, S. Kocić-Tanackov, D. Mladenović, A. Djukić-Vuković, L. Mojović, Brewing and malting technology by-products as raw materials in L-(+)-lactic acid fermentation. J. Chem. Technol. Biotechnol. 95(2), 339-347 (2018). https://doi.org/10.1002/jctb.5878

249. M. Jiang, K. Chen, Z. Liu, P. Wei, H. Ying, H. Chang, Succinic Acid Production by Actinobacillus succinogenes Using Spent Brewer's Yeast Hydrolysate as a Nitrogen Source. Appl. Biochem. Biotechnol. 160, 244-254 (2010). https://doi.org/10.1007/ s12010-009-8649-1

250. K.Q. Chen, J. Li, J.F. Ma, M. Jiang, P. Wei, Z.M. Liu, H.J. Ying, Succinic acid production by Actinobacillus succinogenes using hydrolysates of spent yeast cells and corn fiber. Bioresource Technol. 102(2), 1704-1708 (2011). https://doi.org/10.1016/j. biortech.2010.08.011 